\title{
QUANTIFICAÇÃO DE MICÉLIO EXTRARRADICULAR DE FUNGOS MICORRÍZICOS ARBUSCULARES EM PLANTAS CÍTRICAS
}

\author{
ROGÉRIO MELLONI \\ Engenheiro Agrônomo
}

Orientadora: Profa. Dra. ELKE JURANDY BRAN NOGUEIRA CARDOSO

Dissertação apresentada à Escola Superior de Agricultura 'Luiz de Queiroz", da Universidade de São Paulo, para obtenção do título de Mestre em Agronomia, Área de Concentração: Solos e Nutrição de Plantas.

P I R A C I C A B A

Estado de São Paulo - Brasil

Novembro - 1996 
Dados Internacionais de Catalogação na Publicação (CIP) DIVISÃO DE BIBLIOTECA E DOCUMENTAÇẪO - Campus "Luiz de Queiroz"/USP

Melloni, Rogério

Quantificação de micélio extrarradicular de fungos micorrizicos arbusculares

em plantas citricas / Rogério Melloni. - Piracicaba, 1996.

83p. : il.

Dissertação (mestrado) - Escola Superior de Agricultura Luiz de Queiroz, 1996. Bibliografia.

1. Fruta cítrica - Micorriza 2. Fungo micorrizico - Micélio - Análise quantitativa

3. Micorriza 4. Porta-enxerto de fruta citrica I. Titulo

CDD 634.3 


\title{
QUANTIFICAÇÃO DE MICÉLIO EXTRARRADICULAR DE FUNGOS MICORRÍzICOS ARBUSCULARES EM PLANTAS CÍTRICAS
}

\author{
ROGÉRIO MELLONI
}

Aprovada em: $\quad 17.12 .1996$

Comissão Julgadora:

Profa. Dra. Elke Jurandy Bran Nogueira Cardoso ESALQ/USP

Profa. Dra. Siu Mui Tsai CENA/USP

Profa. Dra. Adriana Parada Dias da Silveira IAC

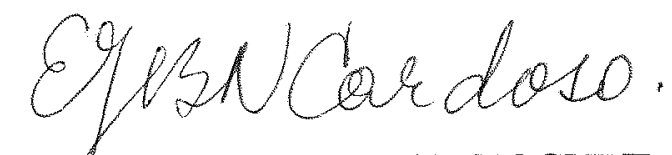

Profa Dra. ELKE JURANDY BRAN NOGUEIRA CARDOSO Orientadora 
Dedico esta dissertação e parte desta vida acadêmica aos meus pais Octavio e Helena e a toda minha familia, que sempre me apoiaram e contribuíram para mais esta conquista. Sem eles, certamente, eu não teria conseguido nada do que agora tenho ... 


\section{AGRADECIMENTOS}

- À Profa. Dra. Elke Jurandy Bran Nogueira Cardoso pela orientação e contribuição à minha formação científica e pessoal;

- Ao Prof. Dr. Márcio Rodrigues Lambais pelo apoio e amizade;

- Aos técnicos de laboratório Fernando Baldesin e Denise de Lourdes Colombo Mescolotti pela inestimável colaboração e amizade;

- Aos amigos que partilharam comigo o ambiente de trabalho: Marcelo, Vânia, Vicente, Marco, Arnaldo, Renata, Ozinaldo, Heron, Cleide, Peterson, Beth, Roberto, Leandra, Carol e Cris;

- Ao CNPq pela bolsa de estudos;

- À FAPESP pelos materiais e equipamentos utilizados;

- À ESALQ e ao Departamento de Ciência do Solo pela oportunidade;

- A todos aqueles que, de uma forma ou outra, contribuíram para que este trabalho se tornasse realidade. 


\section{ÍNDICE}

Página

LISTA DE FIGURAS ......................................................... vi

LISTA DE TABELAS ......................................................... ix

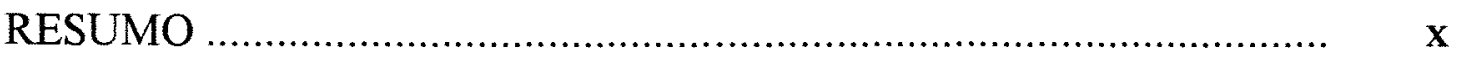

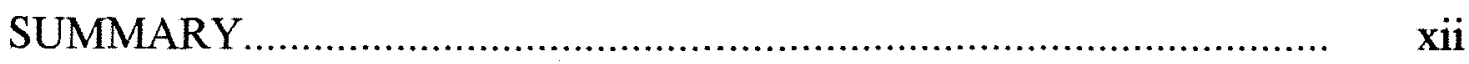

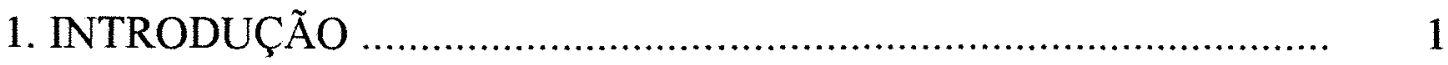

2. REVISÃO DE LITERATURA ….............................................

3. MATERIAL E MÉTODOS ….................................................... 17

3.1. Em casa-de-vegetação ............................................................. 17

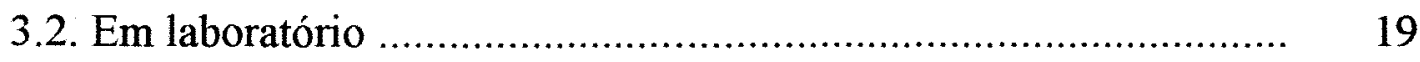

3.2.1. Avaliação da porcentagem de colonização radicular ........... 20

3.2.2. Avaliação da atividade de micélio extrarradicular dos

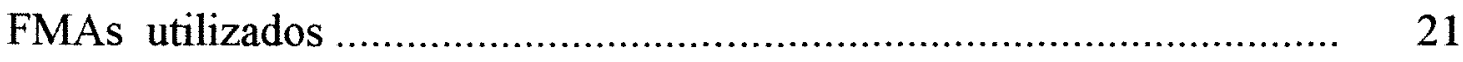

3.2.2.1. Extração de micélio extrarradicular do substrato .. $\quad 21$

3.2.2.2. Quantificação de micélio extrarradicular ativo e total pelo método da fluorescência induzida com diacetato de fluoresceína (FDA)

3.2.2.3. Quantificação de micélio extrarradicular ativo e total pelo método da redução do iodonitrotetrazólio (INT) 
3.2.2.4. Cálculo do comprimento de micélio extrarradicular, utilizando $500 \mathrm{ml}$ de suspensão do liqüidificador como volume de alíquota retirado e $5 \mathrm{ml}$ de suspensão de micélio do frasco de penicilina

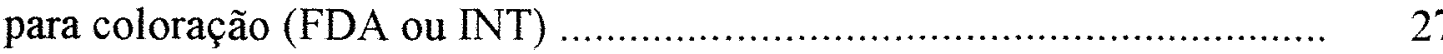

4. RESULTADOS E DISCUSSÃO ……........................................ 30

4.1. Altura de planta, diâmetro do caule, matéria seca da parte aérea e porcentagem de colonização radicular ............................................... 30

4.2. Absorção de nutrientes pelas plantas cítricas ................................ 42

4.3. Micélio extrarradicular ativo (MEA) e total (MET) de FMAs ....... 52

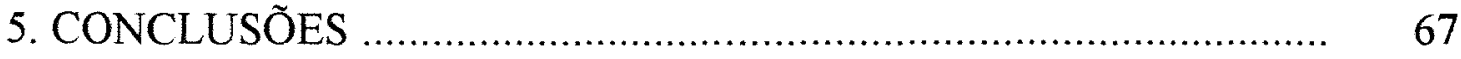

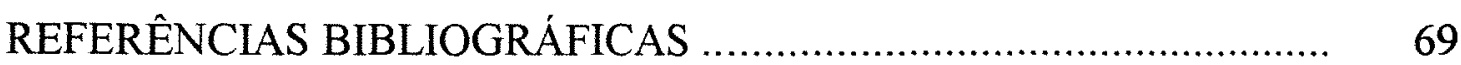




\section{LISTA DE FIGURAS}

Página

Figura 1. Altura de planta (a) e matéria seca da parte aérea (b) dos portaenxertos laranja caipira e tangerina cleópatra, em função da adição de doses crescentes de $\mathrm{P}$ ao substrato (média de 20 repetições)

Figura 2. Correlação entre altura e matéria seca da parte aérea para laranja caipira (a) e tangerina cleópatra (b)

Figura 3. Altura de planta (a) e matéria seca da parte aérea (b) dos portaenxertos laranja caipira e tangerina cleópatra colonizados ou não por FMAs em função da aplicação de doses crescentes de $\mathrm{P}$ ao substrato (média de 10 repetições)

Figura 4. Diâmetro do caule dos porta-enxertos laranja caipira e tangerina cleópatra em função da aplicação de doses crescentes de $\mathrm{P}$ ao substrato (média de 40 repetições)

Figura 5. Correlação entre matéria seca da parte aérea e P total absorvido por laranja caipira (a) e tangerina cleópatra (b) 38

Figura 6. Porcentagem de colonização radicular por $G$. intraradices (a) $\mathrm{e}$ por G. clarum (b), nos porta-enxertos laranja caipira e tangerina cleópatra, em função da aplicação de doses crescentes de $\mathrm{P}$ ao substrato (média de 5 repetições) 
Figura 7. Correlação entre $P$ total absorvido pelos porta-enxertos e $\%$ de colonização radicular por $G$. intraradices

Figura 8. Quantidade total absorvida de N, P, Ca e Mg na parte aérea dos porta-enxertos laranja caipira e tangerina cleópatra, em função da aplicação de doses crescentes de $\mathrm{P}$ ao substrato (média de 20 repetições)

Figura 9. Quantidade total absorvida de $\mathrm{S}$ e $\mathrm{K}$ na parte aérea dos portaenxertos laranja caipira e tangerina cleópatra, em função da aplicação de doses crescentes de $\mathrm{P}$ ao substrato (média de 40 repetições)

Figura 10. $\mathrm{P}$ total absorvido pelos porta-enxertos laranja caipira $\mathrm{e}$ tangerina cleópatra colonizados ou não por FMAs, em função da aplicação de doses crescentes de $\mathrm{P}$ ao substrato (média de 10 repetições)

Figura 11. Matéria seca da parte aérea (a) e P total absorvido (b) pelos porta-enxertos, em função das doses de $\mathrm{P}$ aplicadas (de 0 a $250 \mathrm{mg} \mathrm{P} \mathrm{kg}{ }^{-1}$ de substrato) e calculadas ( 300 a $400 \mathrm{mg} \mathrm{P} \mathrm{kg}^{-1}$ de substrato)

Figura 12. Quantidade total absorvida de $\mathrm{Cu}, \mathrm{Fe}$ e $\mathrm{Mn}$ na parte aérea dos porta-enxertos em função da aplicação de doses crescentes de $\mathrm{P}$ ao substrato (média de 40 repetições)

Figura 13. Quantidade total absorvida de $\mathrm{Zn}$ na parte aérea dos portaenxertos laranja caipira e tangerina cleópatra, em função da aplicação de doses crescentes de $\mathrm{P}$ ao substrato (média de 20 repetições)

Figura 14. Comprimento de MEA de FMAs para laranja caipira (a) e tangerina cleópatra (b) determinado por diferentes métodos de avaliação, em função da aplicação de doses crescentes de $\mathrm{P}$ ao substrato (média de 20 repetições) 
Figura 15. Comprimento de MEA de FMAs nos porta-enxertos laranja caipira e tangerina cleópatra, em função da aplicação de doses crescentes de $\mathrm{P}$ (média de 10 repetições)

Figura 16. Correlação entre comprimento de MEA de $G$. intraradices (a) ou G. etunicatum (b) e porcentagem de colonização radicular, em laranja caipira

Figura 17. Correlação entre comprimento de MEA pelo método FDA (a) ou INT (b) e P total absorvido, em laranja caipira

Figura 18. Correlação entre comprimento de MEA pelo método INT e P total absorvido, em tangerina cleópatra

Figura 19. Comprimento de MET de FMAs para os porta-enxertos laranja caipira e tangerina cleópatra, em função da aplicação de doses crescentes de $P$ (média de 40 repetições)

Figura 20. Correlação entre P total absorvido e comprimento de MET de FMAs em tangerina cleópatra

Figura 21. Correlação entre as quantidades totais absorvidas de N, Ca e Mg na parte aérea e comprimento de MEA para laranja caipira e de MET para tangerina cleópatra

Figura 22. Observações de: MET em luz comum (a); MEA pelo método INT em luz comum (b) e MEA pelo método FDA em luz U.V. (c), no aumento de $100 x$ 


\section{LISTA DE TABELAS}

Página

Tabela 1. Resultado da análise química do substrato utilizado

Tabela 2. Altura $(\mathrm{cm})$ e matéria seca da parte aérea $(\mathrm{g})$ dos porta-enxertos (média de 10 repetições)

Tabela 3. Diâmetro do caule ( $\mathrm{mm}$ ) dos porta-enxertos laranja caipira e tangerina cleópatra, colonizados ou não por FMAs (média de 30 repetições)

Tabela 4. Porcentagem de colonização radicular dos porta-enxertos laranja caipira e tangerina cleópatra colonizados por FMAs em função da aplicação de doses crescentes de $\mathrm{P}$ (média de 5 repetições)

Tabela 5. Quantidade acumulada (mg) de N, S, Ca e Mg na parte aérea dos porta-enxertos laranja caipira e tangerina cleópatra, colonizados ou não por FMAs (média de 30 repetições)

Tabela 6. Quantidade acumulada ( $\mu \mathrm{g})$ de $\mathrm{Cu}, \mathrm{Fe}, \mathrm{Mn}$ e $\mathrm{Zn}$ na parte aérea dos porta-enxertos (média de 60 repetições) 


\title{
QUANTIFICAÇÃO DE MICÉLIO EXTRARRADICULAR DE FUNGOS MICORRÍZICOS ARBUSCULARES EM PLANTAS CÍTRICAS
}

\author{
Candidato: ROGÉRIO MELLONI \\ Orientadora: ELKE J.B.N. CARDOSO
}

\section{RESUMO}

A seleção de métodos de avaliação de micélio extrarradicular ativo (MEA) e total (MET) é o primeiro passo para um estudo mais profundo da interação fungo micorrízico arbuscular (FMA) e hospedeiro, já que a absorção e transporte dos nutrientes do substrato ao hospedeiro são realizados respectivamente por tais estruturas fúngicas.

Visando verificar o efeito de diferentes métodos na quantificação de MEA e MET de FMAs, foi realizado um experimento em casa-de-vegetação, com delineamento inteiramente casualizado e esquema fatorial: 3 espécies de FMAs (Glomus intraradices, G. etunicatum e G. clarum) e um controle sem FMA x 6 doses crescentes de $\mathrm{P}\left(0,50,100,150,200\right.$ e $250 \mathrm{mg} \mathrm{P} \mathrm{kg}^{-1}$ de substrato) x 2 porta-enxertos de citros (laranja caipira e tangerina cleópatra), com 5 repetições por tratamento.

Mensalmente, avaliaram-se altura e diâmetro de caule dos portaenxertos e, após 6 meses de transplantio das mudas, colheram-se as plantas. Determinaram-se, então, matéria seca, macro e micronutrientes da parte aérea, 
porcentagem de colonização radicular e comprimento de MEA e MET pelos métodos de fluorescência induzida com diacetato de fluoresceína (FDA) e redução de iodonitrotetrazólio (INT), após aperfeiçoamento de método de extração de micélio extrarradicular em substrato arenoso.

As doses crescentes de $\mathrm{P}$ proporcionaram aumentos das variáveis altura, diâmetro, matéria seca da parte aérea e quantidade total absorvida de macro e micronutrientes por ambos os porta-enxertos, não sendo suficientemente elevadas para provocar efeito depressivo de crescimento, quando micorrizadas. A porcentagem de colonização radicular comportou-se de maneira inversa, diminuindo proporcionalmente ao aumento das doses.

O método modificado de extração de micélio extrarradicular mostrou-se eficiente, proporcionando quantidade adequada de micélio na membrana. Para quantificação de MEA, o método FDA apresentou-se de maior facilidade de identificação quando comparado ao método INT, podendo ser indicado principalmente em altas doses de $\mathrm{P}$ no substrato. Uma redução do comprimento de MEA ao longo das doses de $\mathrm{P}$ foi verificada, enquanto o oposto foi encontrado para o comprimento de MET, para todos os FMAs avaliados. Houve correlação negativa entre comprimento de MEA e quantidade total absorvida de macronutrientes ( $\mathrm{P}, \mathrm{N}, \mathrm{Ca}$ e $\mathrm{Mg}$ ) por laranja caipira, e correlação positiva entre comprimento de MET e a quantidade absorvida por tangerina cleópatra, indicando que possivelmente haveria outros mecanismos de absorção de nutrientes que não pelo MEA. 


\title{
QUANTIFICATION OF EXTRARADICAL MYCELIUM OF ARBUSCULAR MYCORRHIZAL FUNGI ON CITRUS
}

\author{
Candidate: ROGÉRIO MELLONI \\ Adviser: ELKE J.B.N. CARDOSO
}

\section{SUMMARY}

The selection of quantification methods of the active (AEM) and the total extraradical mycelium (TEM) is the first step for a more complete study of the interaction between arbuscular mycorrhizal fungi (AMF) and host plants because the absorption and transport of nutrients occur through these fungal structures.

With the aim to verify the effect of different quantification methods of the active (AEM) and the total extraradical mycelium (TEM) of arbuscular mycorrhizal fungi (AMF), an experiment was conducted under greenhouse conditions, with a completely randomized factorial design and five replicates per treatment. The factors were: 3 species of AMF (Glomus intraradices, G. etunicatum and G. clarum) and one control without AMF x 6 levels of $\mathrm{P}\left(0,50,100,150,200\right.$ and $\left.250 \mathrm{mg} \mathrm{kg}^{-1}\right) \times 2$ citrus species (Citrus sinensis and C. reshni).

Height and diameter of plants were measured monthly, and after 6 months of transplanting, plants were harvested. Weight, macro and micronutrients, root colonization and length of AEM and TEM by the fluorescein 
diacetate (FDA) and INT reduction were evaluated, after improvement of extraradical mycelium extraction from sandy soil.

Increasing levels of $\mathrm{P}$ promoted increases in plant height, diameter, dry weight and macro and micronutrients absorbed by both citrus species. The $\mathrm{P}$ levels, however, were not high enough to promote growth depression of mycorrhizal plants, while a reduction of radicular colonization with increasing P levels was found.

The modified extraradical mycelium extraction method was efficient, promoting an adequate quantity of mycelium on the membranes. The FDA method was superior in the easyness to identify the active mycelium when compared to the INT method, especially at the higher P levels. A reduction of AEM with increasing $P$ levels was verified, whereas TEM increased with the $P$ level for all AMFs tested. There was a negative correlation between AEM and total macronutrients absorbed ( $\mathrm{P}, \mathrm{N}, \mathrm{Ca}$ and $\mathrm{Mg}$ ) by Citrus sinensis, and a positive correlation between TEM and those macronutrients by C. reshni, indicating that possibly there are other mechanisms of nutrient absortion than by AEM. 


\section{INTRODUÇÃO}

Os efeitos benéficos de fungos micorrizícos arbusculares (FMAs) no desenvolvimento vegetal são bastante conhecidos. Aumentos na absorção de diversos nutrientes e água, maior resistência a estresses hídrico e patológico são alguns dos exemplos mais importantes relacionados a esta associação. $O$ sucesso da inoculação artificial de mudas, além da escolha dos fungos e hospedeiros, dependerá também das condições do solo, principalmente da disponibilidade de nutrientes e do uso de defensivos, os quais afetam o grau de colonização micorrízica das mudas (Colozzi-Filho \& Siqueira, 1986).

Já foram registrados trabalhos em que plantas micorrizadas sob altas doses de nutrientes (principalmente fósforo) se apresentavam menos desenvolvidas que outras não colonizadas. Há várias hipóteses que tentam explicar este fenômeno e, entre elas, a de que o FMA desvia esse fósforo para o desenvolvimento do micélio extrarradicular e/ou para o aumento da sua atividade metabólica, ou ainda, para o aumento do comprimento e da atividade deste micélio, sem que ocorra a translocação de nutrientes para a planta, o que constitui basicamente a hipótese do presente trabalho. Um desbalanço no desenvolvimento micelial do FMA poderia ser a causa deste fenômeno negativo para a citricultura mundial (Eissenstat \& Graham, 1990; Peng et al, 1993).

$\mathrm{Na}$ avaliação de uma planta micorrizada, geralmente se faz uma análise visual da parte interna da raiz, na qual se procura quantificar a extensão de 
colonização interna pelo FMA, considerando as estruturas intrarradicais do respectivo fungo. Esquece-se de que vesículas não apresentam função imediata à planta, podendo, portanto, superestimar a colonização.

Dentre as partes do FMA, o micélio externo à raiz é a que apresenta maior extensão, em comparação com esporos, vesículas ou arbúsculos, concentrando, talvez, maior quantidade de carboidratos destinados ao fungo. Considerando o papel do micélio extrarradicular na eficiência da associação, pode-se inferir que a sua não quantificação ou desprezo seria injustificável a ponto de tornar o estudo de todo o sistema incompleto. A dificuldade em se extrair micélio extrarradicular de um sistema solo-planta micorrizada já é bem conhecida dentro da literatura internacional. São poucos os trabalhos relativos à parte micelial de FMAs, talvez pela dificuldade de extração e/ou identificação. A quantificação de micélio extrarradicular total tende a não ser suficiente em estudos de absorção de nutrientes, uma vez que somente os micélios ativos seriam capazes de absorver os nutrientes minerais e translocá-los até a planta. Portanto, métodos como a fluorescência induzida com diacetato de fluoresceína (FDA) e a redução de iodonitrotetrazólio (INT), entre outros, podem ser encontrados para avaliação de micélio ativo. Não existe, ainda, na literatura, uma comparação destes métodos de quantificação de micélio extrarradicular ativo para espécies cítricas e, portanto, desconhece-se até que ponto os resultados obtidos através dos diferentes métodos possam diferir para o mesmo sistema. Segundo Sylvia (1992), os principais problemas encontrados na quantificação de micélio extrarradicular são a dificuldade de se distinguir hifas de FMAs de fungos não micorrízicos; problemática na visualização de hifas ativas e existência de técnicas muito trabalhosas e consumidoras de tempo.

Portanto, os principais objetivos deste trabalho foram otimizar uma metodologia de extração de micélio extrarradicular de FMAs em substrato 
arenoso, comparar dois métodos de quantificação de micélio extrarradicular ativo e total de FMAs (FDA e INT) e relacionar as variáveis medidas com o fenômeno de depressão de crescimento em plantas cítricas micorrizadas, submetidas a altas doses de fosfato, em casa-de-vegetação. 


\section{REVISĀO DE LITERATURA}

Os efeitos de fungos micorrízicos arbusculares (FMAs) sobre o desenvolvimento do hospedeiro são geralmente bem estudados e conhecidos, principalmente no que se relaciona à nutrição vegetal. Aumentos na velocidade de desenvolvimento de mudas micorrizadas em mais de 4,5 vezes (Colozzi-Filho et $a l, 1994)$, incrementos de até $500 \%$ na altura e $1680 \%$ na produção de matéria seca da parte aérea de mudas de citros (Cardoso et al, 1986), podendo chegar até $2600 \%$ no crescimento das mesmas (Menge et al, 1978), entre outros, comprovam o efeito da associação micorrízica no crescimento vegetal (Siqueira et ah, 1986; Reena \& Bagyaraj, 1990; Souza et al, 1991; Jayachandran et al, 1992). O emprego desses fungos, já no preparo das mudas (Antunes \& Cardoso, 1991; Souza et al, 1991) seria a forma mais racional de sua introdução no ambiente solo. Entretanto, por diversos problemas ligados à produção de inóculo (necessidade de cultivo de plantas colonizadas em condições controladas), ausência de entidades que se responsabilizem por um banco de manutenção e multiplicação das espécies micorrízicas e, ainda, falta de pesquisa nesse sentido em condições tropicais (Zambolim \& Siqueira, 1985), geralmente a utilização se restringe apenas a viveiros e pequenas plantações. Um desenvolvimento mais rápido pela micorrização tenderia a reduzir o custo de formação de mudas pela menor permanência no viveiro, permitindo a comercialização e transplante em menor periodo de tempo (Colozzi-Filho \& Siqueira, 1986). 
Plantas com sistema radicular profundo e pobre em raizes capilares, como citros, são altamente micotróficas e dependentes de FMAs para absorver nutrientes (principalmente P) e se desenvolver (Menge et al, 1978; Fernandes et al, 1987; Lambais \& Cardoso, 1990; Fonseca et al, 1994). Esse efeito benéfico no crescimento vegetal está ligado à maior absorção de nutrientes e água, quando a planta se encontra micorrizada (Levy \& Krikun, 1980; Hardie, 1985). O elemento fósforo é atualmente o mais importante nesse complexo nutricional pelo fato de ser pouco disponível, apresentar baixa mobilidade e estar em baixa concentração no solo (Lobo \& Silva, 1984; Brady, 1989). A utilização de FMAs torna-se economicamente viável e racional pois através deles é possível aproveitar a pequena quantidade de $\mathrm{P}$ presente na solução do solo, reduzindo o uso de insumos. Portanto, a maior parte dos trabalhos que trata desses endófitos estuda o efeito do fungo na absorção de $\mathrm{P}$ e de outros nutrientes no desenvolvimento do hospedeiro (Menge et al, 1978; Lambert et al, 1979; Fernandes et al, 1987; Lambais \& Cardoso, 1990; Fonseca et al, 1994; Tobar et $a l, 1994)$. Como as fontes naturais de fósforo estão se esgotando (Lobo \& Silva, 1984; Brady, 1989) e os adubos fosfatados solúveis são geralmente onerosos (Menge et al, 1978), qualquer substituição ou melhor utilização, até mesmo das fontes orgânicas de P no solo (Jayachandran et al, 1992), seria benvinda dentro de um processo agrícola sustentável. A questão se complica quando da seleção de espécies de FMAs competitivas com a comunidade natural do solo, já que em estudos normalmente se utilizam solos esterilizados em casas-de-vegetação para reduzir o número de interferentes no sistema e o fenômeno da competição somente poderia ser avaliado em campo. Em produções comerciais de mudas de citros se utilizam solos não esterilizados, onde a infestação com FMAs poderia selecionar as espécies mais competitivas e promover maior desenvolvimento das mudas já em condições de campo. Existem poucas informações nesta área e estas 
são de difícil generalização, já que o solo é um ambiente muito heterogêneo. A maior absorção de $\mathrm{P}$ por plantas micorrizadas tem sido atribuída a uma maior exploração superficial de solo e à maior capacidade das hifas extrarradiculares em absorver P em baixa concentração (Rhodes \& Gerdemann, 1978; Jasper et al, 1979; Fernandes et al, 1987; Silveira \& Cardoso, 1991; Xiao-Lin et al, 1991; Jayachandran et al, 1992; Sylvia, 1992; Tobar et al, 1994). Para fungos eficientes podem ocorrer aumentos de até $5070 \%$ no $\mathrm{P}$ absorvido na parte aérea (Cardoso et $a l$, 1986). Talvez o $\mathrm{P}$, embora imóvel no solo, seja considerado relativamente móvel no tecido vascular vegetal, e que a presença de grânulos de polifosfatos nas hifas do fungo seja responsável por seu eficiente transporte (Rhodes \& Gerdemann, 1978).

Condições de baixa disponibilidade de $\mathrm{P}$ são geralmente favoráveis à micorrização com a planta tendo o máximo de benefícios da simbiose, enquanto que em altas concentrações de $\mathrm{P}$, a colonização geralmente é inibida ou o crescimento vegetal não é favorecido, podendo até mesmo ser deprimido pela micorrização (Crush, 1976; Hall et al, 1977; Jasper et ah, 1979; Lambert et al, 1979; Stribley et al, 1980; Graham et al, 1981; Buwalda \& Goh, 1982; Snellgrove et al, 1982; Ojala et ah, 1983; Siqueira \& Colozzi-Filho, 1986; Fernandes et al, 1987; Antunes \& Cardoso, 1991; Peng et al, 1993; Lambais \& Mehdy, 1993; Miranda \& Harris, 1994b). Baixa concentração de P na planta parece aumentar a permeabilidade das membranas radiculares a carboidratos solúveis e compostos aminados, com a intensidade de colonização diretamente relacionada aos níveis de carboidratos solúveis nos extratos e exsudatos radiculares (Jasper et al, 1979; Graham et al, 1981; Siqueira et al, 1984; Thomson et al, 1986). Quanto ao fenômeno de depressão de crescimento em plantas micorrizadas submetidas a altas doses de $\mathrm{P}$, este poderia ser determinado por dois processos: um efeito estimulatório através do aumento na absorção de $\mathrm{P}$ e um 
efeito prejudicial causado pelo fungo em relação ao dreno de carboidratos (fotoassimilados) produzidos pelo hospedeiro (Stribley et al, 1980; Buwalda \& Goh, 1982; Siqueira et ah, 1984). Colonizações são predominantemente vesiculares em altos níveis de $\mathrm{P}$, onde as plantas não se beneficiam com a infecção, e arbusculares onde a micorriza promove beneficios com aumento no crescimento vegetal (Hall et al, 1977). Esta afirmação é contestada por Miller et al. (1987), que encontraram dominância de arbúsculos em plantas tratadas com altas doses de $\mathrm{P}$, e a presença de arbúsculos e vesículas quando nas menores doses do elemento. Presença de lipídios em hifas e esporos de FMAs podem ainda provocar dreno de carboidratos do hospedeiro ao endófito, segundo Buwalda \& Goh (1982). Antunes \& Cardoso (1991) discutiram algumas hipóteses do fenômeno de depressão, relacionando o parasitismo (pela introdução de patógenos junto ao inóculo de FMA), competição por $\mathrm{P}$, toxicidade de $\mathrm{P}$ (hipótese mais aceitável dentro do trabalho de pesquisa realizado), competição entre endófito e hospedeiro por carboidratos ou ainda, a combinação de $\mathrm{P}$ com metais pesados na planta micorrizada, provocando inibição de crescimento. Muitos trabalhos de pesquisa revelam que a dependência micorrízica é inversamente proporcional à quantidade de P disponível no substrato (Mosse \& Phillips, 1971; Cardoso et al, 1986; Thomson et al, 1986; Fernandes et al, 1987; Miranda et al, 1989).

Segundo Kucey \& Paul (1982), a colonização micorrízica é usualmente confirmada por exame microscópico de segmentos de raizes coradas (Newman, 1966; Phillips \& Hayman, 1970; Reicosky et al, 1970; Ambler \& Young, 1977; Biermann \& Linderman, 1980; Giovannetti \& Mosse, 1980; Kormanik et al, 1980; Kormanik \& McGraw, 1982; Toth \& Toth, 1982; Miller et $a l, 1987)$. Esta técnica é adequada para determinar a presença ou confirmar que plantas-controle não colonizadas estão, de fato, sem colonização, mas não indica a quantidade ou tipo de biomassa fúngica. 
O efeito de $\mathrm{P}$ do substrato sobre a micorrização ocorre na fase de crescimento rápido com o desenvolvimento de micélio extrarradicular, múltiplas infecções e extensivo desenvolvimento interno de cada espécie de FMA (Hall et al, 1977; Graham et al, 1982; Abbott \& Robson, 1985). Uma alta concentração de $\mathrm{P}$ no substrato reduziria o crescimento do micélio extrarradicular, reduzindo o desenvolvimento fúngico por infecções secundárias. Crush (1976), constatou que o crescimento de micélio extrarradicular em leguminosas, pelo contrário, é estimulado em altas doses de $\mathrm{P}$, podendo reduzir o crescimento do hospedeiro em até $16 \%$ pela competição por fotoassimilados. Salientou ainda, que o crescimento micelial de FMA nestes altos níveis de $\mathrm{P}$ parece não estar ligado à raiz, assemelhando-se a um patógeno sem causar descoloração ou hipertrofia do tecido radicular, e que a presença de raízes do hospedeiro ou a presença de $\mathrm{P}$ não interferem na germinação de esporos. Cardoso Filho (1994) também verificou tendência de aumento do comprimento de micélio extrarradicular de Glomus etunicatum com o aumento de doses de P, em milho. Ainda, Miranda et al.(1989) afirmaram que o conteúdo de $\mathrm{P}$ na planta teria um importante papel no estabelecimento da simbiose micorrízica, mas que a maioria dos resultados sugere que esse $\mathrm{P}$ não poderia explicar todos os fenômenos observados, evidenciando a importância do $\mathrm{P}$ do solo, principalmente nos estádios iniciais de infecção radicular, quando o FMA está se desenvolvendo no solo (Lambais \& Cardoso, 1988). Jasper et al. (1979) já relacionaram a redução da formação de micorriza com o aumento da concentração de $\mathrm{P}$ foliar, e não com a alta quantidade de $\mathrm{P}$ aplicada ao solo. Estes autores argumentaram que altas concentrações de $P$ nas células vegetais provocariam resistência à infecção micorrízica.

Outros autores relatam que baixas concentrações de $\mathrm{P}$ na planta promovem maior desenvolvimento de micélio extrarradicular (Schwab et al, 1983; Abbott et al, 1984; Abbott \& Robson, 1985; Miller et al, 1987; Miranda et 
$a l, 1989$; Miranda \& Harris, 1994a,b), assim como diferentes fontes de P, com destaque para fosfato de cálcio (Silva et al, 1991) e diferentes espécies de FMAs (Jakobsen et al, 1992). Um estudo para se comprovar a importância da rede micelial de FMAs na colonização radicular e na absorção de $\mathrm{P}$ foi realizado por Jasper et al.(1989). Os resultados comprovaram a hipótese de que a ruptura da rede micelial interromperia o fluxo de assimilados pela mesma, mas que os micélios destacados ainda poderiam infectar raizes, por reterem uma certa quantidade de energia na própria hifa ou em estruturas de reserva. Glomus sp, em geral, produziu esporos precocemente e apresentou pequeno ou nenhum período de dormência. Portanto, o desenvolvimento micelial é um importante fator na determinação da capacidade de FMA em aumentar o crescimento vegetal, mas o comprimento de micélio extrarradicular e sua distribuição no solo são, geralmente, de dificil avaliação (Graham et al, 1982; Abbott et al, 1984; Abbott \& Robson, 1985; Sylvia, 1992; Vilariño et al, 1993; Cardoso Filho, 1994).

Segundo Sylvia (1992), dentre os métodos indiretos de quantificação de micélio extrarradicular, destacam-se: colonização de plantas receptoras, agregação do solo às raizes de plantas micorrizadas e determinação de quitina no substrato.

Alguns pesquisadores têm utilizado o método de colonização de plantas receptoras separadas de uma doadora inoculada, estimando a distância que as hifas de FMAs conseguem percorrer no solo. Talvez se subestime o nivel de crescimento de micélio, uma vez que a colonização não é instantaneamente feita pelo contato hifa-raiz. Em um sistema com hifas abundantes, encontrou-se que apenas um dia era suficiente para contato e penetração, e de dois a três dias para o desenvolvimento de arbúsculos. Xiao-Lin et al (1991) utilizaram o mesmo princípio do método e cultivaram trevo em recipientes com divisões para desenvolvimento da raiz e parte micelial de Glomus mosseae. Concluíram que a 
zona de depleção de $\mathrm{P}$ era consideravelmente maior (acima de $11 \mathrm{~cm}$ de distãncia da raiz) em plantas micorrizadas que nas não micorrizadas, garantindo maior absorção e transporte do elemento, principalmente em condições de desenvolvimento radicular restrito.

$\mathrm{O}$ método de pesagem de solo aderido às raizes de plantas micorrizadas (Sutton \& Sheppard, 1976; Graham et al, 1982; Reena \& Bagyaraj, 1990; Sylvia, 1992), apesar de não ser um método totalmente quantitativo, poderia ser utilizado em comparações relativas de desenvolvimento micelial entre isolados de FMAs.

Um outro método bastante utilizado para quantificação de micélio total presente num substrato é o colorimétrico, na determinação de quitina presente numa amostra de substrato (Hepper, 1977; Sharma et ah, 1977; Bethlenfalvay et al, 1981; Bethlenfalvay et al, 1982; Pacovsky \& Bethlenfalvay, 1982; Bethlenfalvay \& Ames, 1987; Sylvia, 1992; Frey et al, 1994). É um método que não exige aparelhos caros ou experiência do operador (não é um método subjetivo) e que se baseia na determinação de quitina das paredes celulares de FMAs, onde a biomassa fúngica total é de interesse. Amostras de solo seco são autoclavadas com solução concentrada de $\mathrm{KOH}$ para degradar os materiais orgânicos e hidrolizar a quitina do solo e das paredes celulares de FMAs em quitosana; etanol gelado é acrescentado para precipitação da mesma; segue-se uma centrifugação e o pellet é limpo por ressuspensões até a formação de cor através da ação de MBTH, e leitura em espectrofotômetro. Comparam-se essas leituras com curva padrão conhecida (padrões de quitina pura). O conteúdo de quitina no solo aumenta até 10 semanas da inoculação (desenvolvimento micelial) e declina lentamente com a queda de desenvolvimento de FMA (produção de vesículas), autólises de hifas senescentes e eventual decomposição de micélio morto por bactérias. Apesar da relação encontrada entre quantidade de 
glucosamina e porcentagem de colonização (Hepper, 1977), haveria vários problemas ao se considerar esta substância como um indicador da biomassa fúngica, uma vez que há substâncias interferentes no solo como aminoaçúcares nativos (Johnson \& McGill, 1994). Ainda, este método é muito criticado (Frey et $a l, 1994)$ por não distinguir micélio vivo de morto, micélio de FMAs e de outros fungos sapróbios, variar com a idade e condições da cultura (concentrações de oxigênio, água e temperatura), não distinguir biomassa fúngica da de microfauna (exoesqueletos de microartrópodes) e por não considerar a presença de fungos patogênicos e ovos de alguns insetos dentro das raizes. Com isso, a maioria dos autores sugere estudos de novas substâncias (ácidos graxos poliinsaturados específicos) ou conciliação de métodos como microscópicos e imunológicos na real quantificação do comprimento de micélio extrarradicular. Bethlenfalvay et al. (1982) compararam o método colorimétrico com o método histológico (montagem de lâminas de microscopia com segmentos radiculares corados) para análise de colonização e observaram correlação significativa entre os dois métodos até aproximadamente $60 \%$ de colonização. O método colorimétrico, então, seria indicado para casos em que se esperariam altos índices de colonização, pela dificuldade que se teria no método histológico de se detectar diferenças entre altas intensidades. Os autores concluem, salientando que o comprimento de micélio extrarradicular não poderia ser calculado por ambos os métodos.

Entre os métodos diretos de quantificação de micélio extrarradicular de FMAs (Sylvia, 1992), estão o da membrana de filtração (azul de tripano, iodonitrotetrazólio- INT e fluorescência induzida com diacetato de fluoresceína-FDA) e o de imunofluorescência.

$\mathrm{O}$ método de extração e contagem de micélio em membrana quadriculada é realizado, genericamente, pela pesagem de uma amostra de solo, adição de um volume conhecido de água ou solução tampão, agitação da 
suspensão, peneiramento, coloração com corante específico, filtração a vácuo em membrana de filtração quadriculada e quantificação em microscópio (Miller et al, 1987; Sylvia, 1988). São contados todos os segmentos de micélio que interceptam determinadas linhas horizontais (contidas em uma área conhecida da membrana) e esse número "n" de interseções é aplicado na equação de Newman (1966):

$$
\mathrm{R}=(\mathrm{A} \cdot \mathrm{n} \cdot \pi) / 2 . \mathrm{H} \text {, onde: }
$$

$\mathrm{R}=$ comprimento das hifas dentro da área avaliada na membrana $(\mathrm{mm})$

$\mathrm{A}=$ área da membrana avaliada $\left(\mathrm{mm}^{2}\right)$

$\mathrm{H}=$ comprimento das linhas horizontais dentro da área avaliada (mm)

Conhecendo-se a massa de solo seco na amostra original, a massa do solo suspensa na água, o volume de suspensão transferido à membrana, e a proporção do total da membrana observada microscopicamente, é possivel estimar o comprimento de micélio por grama da amostra original de solo seco. $\mathrm{O}$ grande problema deste método é que hifas de fungos não micorrízicos não se distinguem daquelas de FMAs, já que não se notam diferenças morfológicas ou de coloração entre ambas. Uma saída é subtrair o comprimento de hifa dos tratamentoscontrole daqueles inoculados com FMAs (Sylvia, 1992). Outros métodos de extração de micélio foram sugeridos por Schubert et al. (1987) e Cardoso Filho (1994). Emprego de soluções de sacarose para limpeza de micélio e uso de centrifugações diferem os primeiros autores do segundo, que apresenta um método de extração relativamente prático e baseado nos dois métodos citados anteriormente. Vilariño et al. (1993) desenvolveram um extrator elétrico de micélio extrarradicular, onde o micélio capturado poderia ser pesado diretamente em membrana. Salientam a importância do extrator na avaliação da biomassa fúngica em estudos de campo, especialmente em solos arenosos, e a necessidade, 
ainda, de otimizar o método para obtenção de micélio mais limpo e com menores perdas.

Segundo Sylvia (1988), independente da importância do micélio extrarradicular na absorção e translocação de nutrientes, muitos pesquisadores têm se dedicado ainda à simples quantificação das hifas de FMAs no solo, sem distinção de atividade fúngica (Sylvia, 1986; Miller et ah, 1987). Uma vez que a absorção de $\mathrm{P}$ por fungos é um processo ativo, a quantificação de micélio ativo é de extrema importância. Recentemente, corantes que diferenciam células metabolicamente ativas das inativas têm sido usados para se estimar a viabilidade de micélio de FMAs, apesar dos vários métodos, geralmente, não fornecerem resultados homogêneos (Hamel et al, 1990).

Benefield et al. (1977) testaram vários compostos de tetrazólio e escolheram INT como aceptor de $\mathrm{H}^{+}$, por ser aquele que mais competia com o oxigênio pelos elétrons liberados na respiração (redução mais rápida), por garantir extrema sensibilidade e por formar uma cor vermelha quando reduzido, facilitando a visualização. Dentro deste conceito, tem sido usada a redução de sal de tetrazólio para diferenciar micélio ativo de morto ou inativo, tanto em raizes quanto no solo, pela indicação da presença de desidrogenases envolvidas no ciclo de Krebs e cadeia respiratória, em organismos vivos. Uma suspensão com micélio é incubada com solução contendo iodonitrotetrazólio -INT, NADH e TRIS 0,2M, antes da filtração a vácuo em membrana quadriculada e avaliação em microscópio, aplicando posteriormente a equação de Newman (Sylvia, 1988; Hamel et al, 1990; Sylvia, 1992; Cardoso Filho, 1994). Este último constatou diminuição de comprimento de micélio ativo com a idade da cultura de milho, de 30 a 90 dias, e também a redução da mesma variável com o aumento das doses de $\mathrm{P}$ utilizadas, pelo mesmo método INT de avaliação da atividade micelial de Glomus etunicatum. 
Outro corante que pode ser utilizado é o diacetato de fluoresceina - FDA (Medzon \& Brady, 1969; Söderstrom, 1977; Ames et al, 1982; Roser et al, 1982; Ingham \& Klein, 1984; Schubert et al, 1987; Hamel et al, 1990; Sylvia, 1992). FDA é usado como um indicador de esterases, enzimas envolvidas na hidrólise de ésteres de ácidos graxos, que compreendem reserva de energia para a maioria das células vivas. A molécula apolar desse corante seria absorvida pelo fungo e, se as enzimas especificas estivessem presentes, FDA se hidrolizaria e acumularia fluoresceína (adquiriria polaridade e não sairia da célula), que se tornaria fluorescente quando excitada com luz ultravioleta. Segundo Medzon \& Brady (1969), o FDA foi o substrato que mais facilmente penetraria na célula e que a tornaria fluorescente quando absorvido. Então, segmentos de hifas ou pedaços de outras estruturas fúngicas ativas fluoresceriam quando observados em microscópio de fluorescência. Suspensões de micélio seriam incubadas com solução FDA por alguns minutos e filtradas em membranas quadriculadas, antes da observação e contagem em microscópio.

A atividade dos micélios tenderia a diminuir ao longo do tempo de colonização (Sylvia, 1988), não ligada ao desenvolvimento de estruturas reprodutivas e nem senescência da planta (Schubert et al, 1987). Assumindo um certo cuidado em considerar uma relação entre fluorescência e atividade, os resultados sugerem que o micélio extrarradicular é composto de duas partes: uma fluorescente e quase certamente viável, a qual poderia absorver e translocar $\mathrm{P}$, e uma outra não fluorescente (após poucas semanas de colonização radicular) e provavelmente não viável, a qual somente poderia ser capaz de translocá-lo (Schubert et al, 1987). Roser et al. (1982) discutem a utilização de FDA, já que para melhor eficiência, o fungo deveria se apresentar na fase de crescimento ativo e não estar na forma de estruturas dormentes, como esporos maduros. Os autores indicaram a utilização de FDA associado ao brometo de etídio, que possui 
eficiência tanto em estruturas vivas dormentes (conídios e clamidosporos) quanto em células de crescimento ativo, e que quando incorporado aos constituintes celulares, primeiramente tornaria os ácidos nucléicos fluorescentes, diretamente proporcional à presença destes. Hamel et al.(1990) concluíram que a porcentagem de colonização radicular ativa diminuía com a idade da simbiose. Observaram um comportamento diferenciado entre micélio intra e extrarradicular de Glomus intraradices, onde o primeiro apresentou pouca variação de atividade, provavelmente por estar protegido pela raiz, enquanto o segundo, mais sujeito ao ataque de outros microrganismos, maior variação dessa característica.

O método de autofluorescência (Darken, 1961) pode ser usado para quantificação de colonização radicular, mas não à avaliação de micélio total ou ativo, já que este não apresenta autofluorescência. Esta fluorescência se limitaria apenas aos arbúsculos dentro das raízes, descartando a avaliação de outras estruturas fúngicas como hifas, esporos e vesículas, independente do FMA, do hospedeiro ou das condições ambientais (Ames et al, 1982; Kormanik \& McGraw, 1982). A autofluorescência dos arbúsculos estaria mais relacionada às estruturas do hospedeiro do que propriamente ao fungo, já que os mesmos, quando inativos e não funcionais, mantinham ainda a fluorescência. Estas estruturas seriam, então, de difícil distinção usando a própria luz do microscópio (Ames et al, 1982).

Outra técnica que pode ser utilizada na quantificação e identificação de micélio extrarradicular é a imunofluorescência (Wilson et al, 1983; Kough et al, 1983; Sylvia, 1992). Identificação de FMAs tem sido problemática quando na distinção entre FMA e fungo não micorrízico. Para isso, existe um método específico em que se produz um antissoro em animal, usando antígeno de parede celular de hifas coletadas de esporos de FMAs em germinação. Este antissoro poderia ser usado posteriormente como técnica de 
anticorpo fluorescente (em microscópio de fluorescência) para distinguir espécies de FMAs e de outros microrganismos do solo. É uma técnica difícil, já que se exige um material fúngico puro a ser usado como antígeno, e a complicação se torna ainda maior pela impossibilidade de se cultivar FMAs na ausência de hospedeiro vivo. 


\section{MATERIAL E MÉTODOS}

\subsection{Em casa-de-vegetação}

Foi instalado um experimento em casa-de-vegetação, em esquema fatorial: 3 espécies de FMAs (Glomus intraradices, Glomus etunicatum e Glomus clarum) e um controle sem fungo micorrizico x 6 doses crescentes de $\mathrm{P}(0,50$, $100,150,200$ e $250 \mathrm{mg} \mathrm{P} \mathrm{kg}^{-1}$ de substrato na forma de $\mathrm{KH}_{2} \mathrm{PO}_{4}$ e $\mathrm{NaH}_{2} \mathrm{PO}_{4} \cdot \mathrm{H}_{2} \mathrm{O}$ ) x 2 porta-enxertos de citros: laranja caipira (Citrus sinensis) e tangerina cleópatra (Citrus reshni), com 5 repetições por tratamento, num total de 240 vasos plásticos de 5 litros cada. O substrato a ser utilizado foi composto de 3 partes de solo Areia Quartzosa, série Paredão Vermelho, para 1 parte de areia de rio peneirada e lavada, e autoclavado por 2 horas a $121^{\circ} \mathrm{C}$. Foi feita análise química do substrato (Tabela 1) para correção de acidez (com calcário dolomítico PRNT 131\%) e adubação com macro (40 mg N kg${ }^{-1}$ de substrato, $48 \mathrm{mg} \mathrm{S} \mathrm{kg}^{-1}$ de substrato e 50 $\mathrm{mg} \mathrm{K} \mathrm{kg}{ }^{-1}$ de substrato) e micronutrientes (solução contendo $\mathrm{B}, \mathrm{Zn}, \mathrm{Cu}$, Mo e FeEDTA), de acordo com Antunes \& Cardoso (1991), repetindo a adubação nitrogenada nos 2 meses consecutivos ao transplantio.

As sementes dos porta-enxertos de citros foram obtidas da Estação Experimental de Cordeirópolis (SP), do Instituto Agronômico de Campinas, semeadas e conduzidas por 3 meses, em caixas de areia esterilizada, dentro de casa-de-vegetação, para obtenção das plântulas. 
Tabela 1. Resultado da análise química do substrato utilizado.

\begin{tabular}{lc}
\hline Parâmetros avaliados & Valores \\
\hline $\mathrm{pH}\left(\mathrm{CaCl}_{2}\right)$ & 3,8 \\
M.O. $\left(\mathrm{g} \mathrm{dm}^{-3}\right)$ & 11 \\
P resina $\left(\mathrm{mg} \mathrm{dm}^{-3}\right)$ & 3 \\
$\mathrm{~K}^{+}\left(\mathrm{mmol}_{\mathrm{c}} \mathrm{dm}^{-3}\right)$ & 0,2 \\
$\mathrm{Ca}^{+2}\left(\mathrm{mmol}_{\mathrm{c}} \mathrm{dm}^{-3}\right)$ & 7 \\
$\mathrm{Mg}^{+2}\left(\mathrm{mmol}_{\mathrm{c}} \mathrm{dm}^{-3}\right)$ & 2 \\
$\mathrm{Al}^{+3}\left(\mathrm{mmol}_{\mathrm{c}} \mathrm{dm}^{-3}\right)$ & 8 \\
$\mathrm{H}^{+}+\mathrm{Al}^{3+}\left(\mathrm{mmol}_{\mathrm{c}} \mathrm{dm}^{-3}\right)$ & 28 \\
$\mathrm{~S}\left(\mathrm{mmol}_{\mathrm{c}} \mathrm{dm}^{-3}\right)$ & 9,2 \\
$\mathrm{~T}\left(\mathrm{mmol}_{\mathrm{c}} \mathrm{dm}^{-3}\right)$ & 37,2 \\
$\mathrm{~V}(\%)$ & 24,7 \\
\hline
\end{tabular}


O substrato foi infestado com os referidos fungos micorrizicos arbusculares (20 g de solo rizosférico de milho Piranão micorrizado), antes do transplantio de 1 muda de citros por vaso e adição de água destilada, sendo que para o substrato controle utilizou-se da mesma medida de solo, obtido de milho não micorrizado.

Mensalmente, determinaram-se:

a) altura das plantas (da superficie do substrato à última folha);

b) diâmetro do caule das plantas (com paquímetro, cerca de $5 \mathrm{~cm}$ da superficie do substrato).

No final do experimento ( 6 meses do transplantio), avaliaram-se:

c) matéria seca da parte aérea (após peso constante em estufa a $60^{\circ} \mathrm{C}$ );

d) porcentagem de colonização radicular (ver item 3.2.1);

e) nutrientes foliares, após moagem, segundo Sarruge \& Haag (1974), com digestão sulfúrica e método de Kjeldahl para $\mathrm{N}$, e digestão nitro-perclórica para os outros elementos, e os métodos: $\mathrm{P}$ por colorimetria, $\mathrm{K}, \mathrm{Ca}, \mathrm{Mg}, \mathrm{Cu}, \mathrm{Zn}, \mathrm{Mn}$ e Fe por espectrofotometria de absorção atômica e $\mathrm{S}$ por turbidimetria;

f) comprimento de micélio extrarradicular ativo (MEA) e total (MET), conforme item 3.2.2.

\subsection{Em laboratório}

Quando da colheita das plantas em casa-de-vegetação, foram retiradas amostras de substrato, acondicionadas em sacos plásticos e congeladas, para estudos de micélio extrarradicular de FMAs. Parte do sistema radicular foi retirada, lavada em água corrente e conservada em solução AFA (ácido acético 
glacial, formol, álcool etilico e água destilada, na proporção em volume de 1:5:20:40), antes da avaliação da porcentagem de colonização radicular.

\subsubsection{Avaliação da porcentagem de colonização radicular}

A porcentagem de colonização radicular foi realizada da seguinte forma (adaptação do método proposto por Phillips \& Hayman, 1970):

a) lavagem das raizes com água de torneira para retirada do AFA;

b) imersão de amostras de raízes em solução de $\mathrm{KOH} 10 \%$ por 1 hora a $90^{\circ} \mathrm{C}$, utilizando estufa ou banho-maria, para comparação e seleção do melhor método (avaliação visual, em microscópio);

c) nova lavagem das raízes em água de torneira;

d) imersão das mesmas em hipoclorito de sódio 1:1 ou diretamente em solução de $\mathrm{HCl} 1 \%$ por 10 minutos;

e) descarte da solução anterior e adição de corante lactoglicerol com azul de tripano, incubando por 10 minutos em banho-maria ou em estufa a $90^{\circ} \mathrm{C}$;

f) descarte do excesso do corante e adição de lactoglicerol incolor para conservação e futura observação em microscópio.

As raizes coradas de cada amostra foram cortadas em segmentos de aproximadamente $1 \mathrm{~cm}$ de comprimento e dispostas em 5 lâminas de microscopia, em grupos de 10 cada, para no final, avaliarem-se 50 segmentos por amostra. Cada segmento de raiz foi visualizado em microscópio e atribuída uma nota variando de 0 a 100, conforme a intensidade de colonização radicular (Giovannetti \& Mosse, 1980; Bethlenfalvay et al, 1981).

O melhor método de coloração das raizes cítricas para determinação da porcentagem de colonização radicular foi obtido utilizando-se banho-maria no processo de clareamento com $\mathrm{KOH} 10 \%$ a $90^{\circ} \mathrm{C}$, uso de $\mathrm{HCl} 1 \%$ 
diretamente sem hipoclorito de sódio, e novamente uso de banho-maria quando da incubação com corante lactoglicerol-azul de tripano. $O$ uso de estufa durante os processos de clareamento e coloração provocou problemas de desintegração de material, enquanto a utilização de hipoclorito de sódio, isolado ou associado ao $\mathrm{HCl}$, causou clareamento excessivo das raízes e posterior deficiência na coloração.

\subsubsection{Avaliação da atividade de micélio extrarradicular dos FMAs utilizados}

O processo de avaliação teve início na fase de extração de micélio extrarradicular do substrato até a sua quantificação em ativo e total.

\subsubsection{Extração de micélio extrarradicular do substrato}

Adaptou-se o método de extração de Cardoso Filho (1994), para a obtenção mais rápida de micélio extrarradicular de FMAs, conforme descrito a seguir:

a) pesaram-se $10 \mathrm{~g}$ de amostra úmida de substrato, paralelamente à pesagem de uma subamostra para determinação do seu teor de água (estufa a $110^{\circ} \mathrm{C}$ por $24 \mathrm{~h}$ ); b) em um béquer de $1000 \mathrm{ml}$ de capacidade, adicionaram-se à amostra de substrato aproximadamente $500 \mathrm{ml}$ de água de torneira, antes da agitação manual com bastão de vidro para quebrar os pequenos aglomerados de substrato;

c) peneirou-se a suspensão de substrato em peneiras de 0,71 e $0,25 \mathrm{~mm}$ de malha, adicionando água de torneira até um volume final de peneirado próximo de 1500 $\mathrm{ml}$; 
d) levou-se a suspensão para liqüidificador, utilizando de pequenas porções de água de torneira, até o volume final de $1500 \mathrm{ml}$, antes da agitação por 30 segundos na menor rotação (velocidade 1).

e) Nesta fase, testaram-se as seguintes alterações:

e.1.) uso ou não de tempos diferentes de repouso no próprio liqüidificador, antes da retirada das aliquotas $(0,1$ e 2 minutos $)$.

e.2) retirada de alíquotas diferentes da suspensão (100, $500 \mathrm{ou} 1000 \mathrm{ml})$, com auxílio de uma proveta, antes do prosseguimento do método;

f) A aliquota foi levada para peneira de $0,044 \mathrm{~mm}$ de malha e o retido foi para frasco de penicilina, utilizando-se pequenas porções de água destilada, até um volume final de $11 \mathrm{ml}$ de suspensão de micélio (marcado no referido frasco).

Após o período de agitação da amostra do substrato e água no liqüidificador, o tempo de $2 \mathrm{~min}$ de repouso da suspensão no próprio recipiente, antes da retirada da alíquota de $500 \mathrm{ml}$, foi fundamental para a obtenção de membranas mais limpas, observando-se o contrário quando da ausência ou menor tempo desta fase. Surgiu a hipótese desse tempo diminuir a representatividade da quantidade de micélio na amostra, mas esta foi esclarecida após observação da pequena variação da quantidade de micélio nos diferentes tempos de repouso empregados. Com este procedimento, diminuíram-se vários passos de limpeza de micélio pelo não uso de solução de sacarose (Schubert et al, 1987; Cardoso-Filho, 1994), reduzindo tanto o tempo de extração de micélio quanto o uso de materiais e reagentes.

A retirada da alíquota de $500 \mathrm{ml}$ foi a que garantiu uma quantidade satisfatória de micélio limpo de impurezas na membrana de filtração, facilitando a contagem em microscópio. Alíquotas de 1000 ou $100 \mathrm{ml}$ proporcionaram excesso ou escassez, respectivamente, de micélio na membrana, além do problema da presença de partículas de argila, prejudicando a contagem. 
O volume final de suspensão de micélio no referido frasco de penicilina $(11 \mathrm{ml})$ garantiu melhor partição da amostra, a qual ocorreu pela divisão de duas alíquotas de $5 \mathrm{ml}$ cada, destinadas ao processo de determinação de atividade (métodos FDA e INT). Um volume "teórico" de $10 \mathrm{ml}$ no frasco de penicilina não garantiu quantidade exata dos volumes exigidos $(5 \mathrm{ml})$ pela dificuldade de se retirar, na prática, as alíquotas com pipeta comum. Uma agitação manual, antes da retirada de cada alíquota, foi fundamental para uma melhor homogeneidade de amostragem, conforme se observará posteriormente pela baixa variação da quantidade de micélio extrarradicular total em ambos os métodos submetidos (FDA e INT). Ensaios com alíquotas de $3 \mathrm{ml}$, retiradas do frasco de penicilina, não apresentaram micélios suficientes para uma contagem satisfatória na membrana e por isso foram descartados.

\subsubsection{Quantificação de micélio extrarradicular ativo e total pelo método da fluorescência induzida com diacetato de fluoresceína (FDA)}

Após extração de micélio extrarradicular, foram testadas diferentes alíquotas dessa suspensão com micélio ( 3 ou $5 \mathrm{ml}$ ) em diferentes volumes de solução de FDA ( 3 ou $5 \mathrm{ml}$ ), preparada de acordo com Schubert (1987) e Sylvia (1992), procurando sempre manter a proporção de $1 \mathrm{ml}$ de suspensão de micélio para $1 \mathrm{ml}$ de solução de FDA. Testou-se o tempo de incubação à temperatura ambiente, 5 ou $10 \mathrm{~min}$, antes da filtração a vácuo em membrana de triacetato de celulose, quadriculada (linhas horizontais e verticais distanciadas de $3 \mathrm{~mm}$ ) de $47 \mathrm{~mm}$ de diâmetro e $0,45 \mu \mathrm{m}$ de porosidade. Cada membrana, após completamente seca (ao ar), foi colocada sobre lâmina quadrada de $25 \mathrm{~cm}^{2}$ contendo pequenas gotas de óleo de amêndoa, e coberta posteriormente com outra lâmina de mesma dimensão, formando um "sanduíche de lâminas", 
antes da demarcação de 64 campos ( 8 x 8 campos), conforme Cardoso Filho (1994), para manter o erro de contagem inferior a $20 \%$, com uma precisão de $95 \%$ de probabilidade.

Em microscópio de epifluorescência (Olympus System Microscope Model BX40), acoplou-se uma ocular reticulada ("grid" de área $100 \mathrm{~mm}^{2}$ contendo 10 linhas horizontais e 10 linhas verticais de $10 \mathrm{~mm}$ cada, no aumento total de 10 vezes) conhecida na literatura internacional como "eye piece whipple disc". Com isso, avaliaram-se 64 campos quadrados de cada membrana, sendo 1 campo do referido "grid" (composto de 100 quadrados) para cada campo da membrana, utilizando o método da interseção ("gridline intersect method"). Avaliou-se o número de interseções de hifas fluorescentes (ativas) com as linhas horizontais dos campos do "grid" da ocular, antes de calcular o comprimento do micélio extrarradicular ativo pela equação de Newman (1966), corrigida pelo teor de água do substrato e volumes das alíquotas utilizadas.

Para contagem de micélio extrarradicular total, fez-se nova contagem dos 64 campos da membrana, seguindo os mesmos cálculos para comprimento de micélio extrarradicular ativo, mas agora avaliados em microscópio sob luz comum.

O método descrito por Schubert (1987) e Sylvia (1992) para determinação de MEA e MET garantiu coloração eficiente quando mantida a relação de $1 \mathrm{ml}$ de solução com diacetato de fluoresceína (FDA) para $1 \mathrm{ml}$ de suspensão de micélio. O tempo de 5 min de incubação à temperatura ambiente foi suficiente para a coloração, não se verificando diferenças visuais com o tempo de $10 \mathrm{~min}$, reduzindo ainda mais o tempo exigido nesta fase.

$\mathrm{O}$ número de campos demarcados para contagem na membrana (64 campos), proposto por Cardoso Filho (1994), demonstrou-se ideal pela abrangência e racionalização de contagem, em microscópio de epifluorescência. 
Este garantiu boa visualização dos micélios em ambas as contagens (micélio ativo e total) e apresentou-se de extrema facilidade de manuseio, principalmente no que se refere ao acoplamento da ocular reticulada ("eye piece whipple disc") em uma das oculares e à utilização de luz de vários comprimentos de onda e contrastes de fase quando necessários.

O método de fluorescência induzida com FDA mostrou ser de grande facilidade na identificação de MEA, reduzindo, portanto, eventuais erros de contagem por um operador pouco experiente. Como desvantagens, poderia ser citada a necessidade de dupla contagem da membrana, pelo fato da exigência de luz ultravioleta para avaliação de MEA e luz comum para avaliação de MET, o que aumentou o tempo de avaliação de micélio extrarradicular por este método; além do custo e manutenção do equipamento envolvido, quando em análise de rotina, por exemplo.

\subsubsection{Quantificação de micélio extrarradicular ativo e total pelo método da redução do iodonitrotetrazólio (INT)}

Após extração de micélio, testaram-se volumes diferentes de suspensão $(3,5$ ou $10 \mathrm{ml})$, para diferentes volumes $(0,5 ; 1,0$ ou $1,5 \mathrm{ml})$ de solução com INT (volumes iguais de solução de $1 \mathrm{mg} \mathrm{INT} \mathrm{ml}^{-1}, 3 \mathrm{mg}^{\mathrm{de} N A D H ~ \mathrm{ml}^{-1} \mathrm{e}}$ TRIS 0,2M pH 7,4 de acordo com Sylvia, 1992). Também incubaram-se por diferentes tempos $(6,8$ ou $10 \mathrm{~h})$ a $28^{\circ} \mathrm{C}$, antes de sofrer ou não a coloração de contraste com solução azul de tripano $0,05 \%$, em diferentes volumes $(0,5 ; 1,0 ; 1,5$ ou $5,0 \mathrm{ml}$ ) e diferentes tempos de incubação $(5,10,15$ ou $30 \mathrm{~min}$ ). Posteriormente, cada membrana foi colocada entre duas lâminas quadradas (conforme descrito para o método FDA, anteriormente) e avaliada em 
microscópio sob luz comum, tanto o micélio ativo (corado de vermelho) quanto o total.

Para este método, assim como para o método descrito anteriormente, a alíquota que melhor garantiu uma quantidade aceitável de micélio na membrana foi a de $5 \mathrm{ml}$ (retirada do frasco de penicilina), adicionada de $1,5 \mathrm{ml}$ de solução com $\mathrm{INT}$ e incubação por 8 horas a $28^{\circ} \mathrm{C}$, antes da contagem em microscópio de luz comum, sem a coloração de contraste com solução de azul de tripano. Alíquotas menores ou maiores de suspensão de micélio, volumes menores de solução com INT, tempos de incubação menores ou maiores e uso de coloração de contraste, dificultaram ou impediram a visualização da cor vermelha apresentada pelas hifas ativas, subestimando-se a atividade. Foi considerado um método pouco eficiente na avaliação de atividade pela dificuldade de identificação das hifas coradas de vermelho, uma vez que se confundiam com as cores naturais apresentadas, além do elevado tempo exigido de incubação a $28^{\circ} \mathrm{C}$. A solução de azul de tripano, quando utilizada para contraste, promoveu a combinação do azul do corante com o vermelho do micélio ativo, dificultando a distinção entre hifas coradas de roxo (ativas) e de azul (inativas ou mortas), como também discutido por Cardoso Filho (1994). Uma vantagem encontrada quando da utilização deste método foi com relação à contagem em microscópio, a qual exigia somente luz comum e contagem de micélio ativo e total de uma só vez por membrana. 
3.2.2.4. Cálculo do comprimento de micélio extrarradicular, utilizando 500 ml de suspensão do liquidificador como volume de alíquota retirado e $5 \mathrm{ml}$ de suspensão de micélio do frasco de penicilina para coloração (FDA ou INT)

A equação de Newman indicou o comprimento de micélio extrarradicular presente em 64 "grids" na membrana, no aumento considerado:

$$
\mathrm{R}=(\pi \cdot \mathrm{A} \cdot \mathrm{n}) / 2 . \mathrm{H}
$$

(1), sendo:

$\mathrm{R}=$ comprimento de micélio extrarradicular presente em 64 "grids" avaliados na membrana, em milímetros;

$\mathrm{A}=$ área dos "grids" avaliados na membrana, no aumento considerado de $10 \mathrm{x}$ $\left(100 \mathrm{~mm}^{2} .64\right)$, em milímetros quadrados;

$\mathbf{n}=$ número de interseções entre as hifas e as linhas horizontais do grid da ocular reticulada;

$\mathrm{H}=$ comprimento total das linhas horizontais do grid da ocular reticulada, no aumento considerado de 10x (100 mm . 64), em milímetros.

Como a área avaliada da membrana acima é bem menor que a área real da mesma, obtida após filtração a vácuo $\left(1320,25 \mathrm{~mm}^{2}\right.$ ou $132025 \mathrm{~mm}^{2}$ no aumento considerado de $100 \mathrm{x}$, sendo $10 \mathrm{x}$ da ocular e 10x da objetiva), um cálculo de correção foi efetuado:

$R$. $(132025 / 6400)=20,629 . R=R_{1}$, indicando o comprimento de micélio extrarradicular presente em toda a área da membrana.

Sabendo que se utilizaram $5 \mathrm{ml}$ da suspensão de micélio como alíquota para coloração, de um volume inicial de $11 \mathrm{ml}$ presente no frasco de penicilina, temos que o comprimento total de micélio contido no interior deste frasco $\left(R_{2}\right)$ seria:

$$
R_{1} \cdot(11 / 5)=R_{2}
$$


Como a quantidade de micélio presente em $11 \mathrm{ml}$ da suspensão $\left(\mathrm{R}_{2}\right)$ é proveniente da alíquota de $500 \mathrm{ml}$ retirada do liquidificador, temos que o comprimento $R_{2}$ de micélio se refere também a essa alíquota. Então, para um volume inicial de $1500 \mathrm{ml}$ (total do peneirado e agitado no liqüidificador), tem-se:

$R_{2} \cdot(1500 / 500)=R_{3}$, indicando o comprimento de micélio presente em todo o volume do peneirado, para $10 \mathrm{~g}$ de amostra de substrato úmido.

Descontando o teor de água do substrato, tem-se o seguinte comprimento de micélio extrarradicular por grama de amostra de substrato seco (RT):

$R T=\left(R_{3} .1\right) / 10-U$, sendo $U$ o teor de água em gramas.

Substituindo os valores das eq. 2,3 e 4 nesta equação (RT), temse:

$$
\begin{aligned}
& \mathrm{RT}=[(20,629 . \mathrm{R}) \cdot(11 / 5) \cdot(1500 / 500)] / 10-\mathrm{U} \\
& \mathrm{RT}=136,15 \cdot \mathrm{R} / 10-\mathrm{U}
\end{aligned}
$$

Calculando o $\mathrm{R}$ da eq. 1 e substituindo na eq. 5, teríamos:

$\mathrm{R}=(\pi \cdot \mathrm{A} \cdot \mathrm{n}) / 2 . \mathrm{H}$, onde:

$\mathrm{R}=[\pi .(100.64) \cdot \mathrm{n}] / 2 .(100.64)$

$\mathrm{R}=1,5708 . \mathrm{n}$

Então, substituindo eq. 7 na eq. 6 :

$\mathrm{RT}=136,15 .(1,5708 . \mathrm{n}) / 10-\mathrm{U}$

$\mathrm{RT}=213,87 . \mathrm{n} / 10-\mathrm{U}$, expresso em $\mathrm{mm} / \mathrm{g}$ de substrato seco,

ou: 
Os cálculos para comprimento de micélio extrarradicular ativo (MEA) e total (MET) de FMAs foram feitos de acordo com a eq. 8, e os dados obtidos submetidos à análise estatística

Fez-se análise de variância dos dados obtidos pelo programa estatístico SANEST (utilizado no Centro de Informática na Agricultura da ESALQ/USP), para se verificar efeitos de doses de fósforo, porta-enxertos e espécies de FMAs, seguido do teste de Tukey a 1\% de significância (representado pelo símbolo “**”) e 5\% (representado pelo símbolo “*”) para comparações das médias, além de análises de regressão, utilizando apenas a transformação raiz quadrada de $(x+0,5)$ para os dados de porcentagem de colonização radicular. 


\section{RESULTADOS E DISCUSSÃO}

\subsection{Altura de planta, diâmetro do caule, matéria seca da parte aérea e porcentagem de colonização radicular}

Verificaram-se efeitos das interações duplas porta-enxertos doses de $\mathrm{P}$ e doses de $\mathrm{P}$ - FMAs nas variáveis altura de planta e matéria seca da parte aérea. $\mathrm{O}$ comportamento destas variáveis nas doses aplicadas de $\mathrm{P}$ está representado nas Figura 1, com efeito linear para o porta-enxerto tangerina cleópatra e quadrático para laranja caipira, revelando uma maior resposta do primeiro ao $\mathrm{P}$. Essas variáveis se comportaram semelhantemente em função das doses de $\mathrm{P}$, com correlação significativa a $1 \%$ de significância, para ambos os porta-enxertos, conforme Figura 2. É um resultado importante, já que a altura de planta pode ser facilmente medida em casa-de-vegetação e o resultado correlacionado com a matéria seca da parte aérea, considerada uma variável mais consistente, visto a variação da altura de plantas por brotações laterais, comuns em plantas cítricas. Portanto, um acompanhamento da altura de planta daria uma boa correlação com sua matéria seca e facilitaria ou anteciparia os resultados de interesse.

O efeito de FMAs em função das doses de $\mathrm{P}$ pode ser verificado na Tabela 2 e Figura 3, onde os fungos G. clarum e G. intraradices se destacam dos demais em praticamente todas as doses de $\mathrm{P}$ e porta-enxertos, com médias superiores e estatisticamente diferentes das de G. etunicatum e controle sem FMA (Tabela 2). 


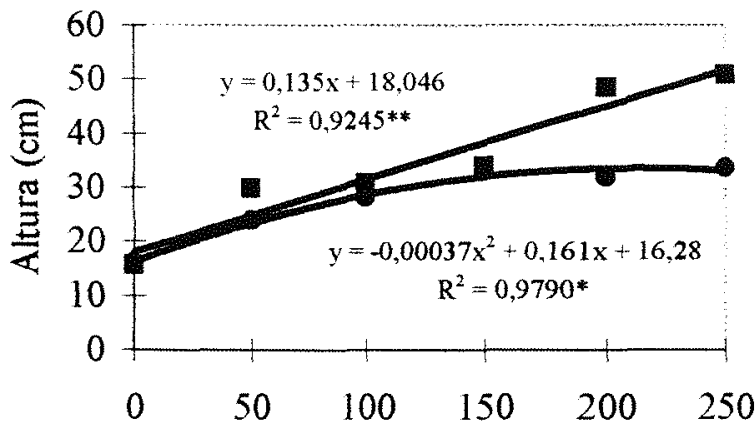

Doses de $\mathrm{P}$ ( $\mathrm{mg} \mathrm{kg}{ }^{-1}$ de substrato) a

- laranja caipira

tangerina cleopatra

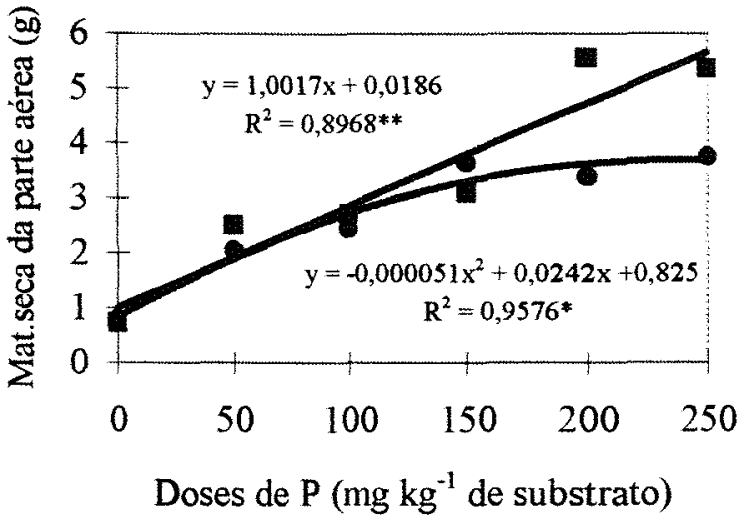

b

Figura 1. Altura de planta (a) e matéria seca da parte aérea (b) dos porta-enxertos laranja caipira e tangerina cleópatra, em função da adição de doses crescentes de $\mathrm{P}$ ao substrato (média de 20 repetições). 
Tabela 2. Altura $(\mathrm{cm})$ e matéria seca da parte aérea $(\mathrm{g})$ dos porta-enxertos (média de 10 repetições).

\begin{tabular}{lrrrrrr}
\hline FMAs & \multicolumn{6}{c}{ Doses de $\mathrm{P}\left(\mathrm{mg} \mathrm{kg}^{-1}\right.$ de substrato) } \\
\hline & 0 & 50 & 100 & 150 & 200 & 250 \\
\hline Controle & $9,1 \mathrm{c}$ & $12,0 \mathrm{~b}$ & $16,3 \mathrm{~b}$ & $20,1 \mathrm{~b}$ & $32,1 \mathrm{bc}$ & $38,7 \mathrm{bc}$ \\
G.intraradices & $22,4 \mathrm{a}$ & $37,4 \mathrm{a}$ & $42,0 \mathrm{a}$ & $42,9 \mathrm{a}$ & $42,5 \mathrm{~b}$ & $46,9 \mathrm{ab}$ \\
G.etunicatum & $9,5 \mathrm{bc}$ & $12,8 \mathrm{~b}$ & $18,2 \mathrm{~b}$ & $21,4 \mathrm{~b}$ & $27,5 \mathrm{c}$ & $29,5 \mathrm{c}$ \\
G.clarum & $21,8 \mathrm{ab}$ & $45,3 \mathrm{a}$ & $41,2 \mathrm{a}$ & $49,6 \mathrm{a}$ & $58,6 \mathrm{a}$ & $53,8 \mathrm{a}$ \\
\hline \multicolumn{7}{c}{ Massa seca da parte aérea (g) } \\
\hline Controle & $0,17 \mathrm{a}$ & $0,35 \mathrm{~b}$ & $1,01 \mathrm{~b}$ & $1,51 \mathrm{~b}$ & $2,91 \mathrm{~b}$ & $3,86 \mathrm{bc}$ \\
G.intraradices & $1,41 \mathrm{a}$ & $3,52 \mathrm{a}$ & $4,16 \mathrm{a}$ & $4,38 \mathrm{a}$ & $4,62 \mathrm{~b}$ & $5,26 \mathrm{ab}$ \\
G.etunicatum & $0,19 \mathrm{a}$ & $0,48 \mathrm{~b}$ & $1,18 \mathrm{~b}$ & $1,75 \mathrm{~b}$ & $2,84 \mathrm{~b}$ & $2,94 \mathrm{c}$ \\
G.clarum & $1,24 \mathrm{a}$ & $4,84 \mathrm{a}$ & $3,99 \mathrm{a}$ & $5,80 \mathrm{a}$ & $7,45 \mathrm{a}$ & $6,12 \mathrm{a}$ \\
\hline
\end{tabular}

Comparam-se letras na vertical entre FMAs. Médias seguidas por letras iguais não diferem entre si, ao nivel de $5 \%$ de significância, pelo teste de Tukey. 

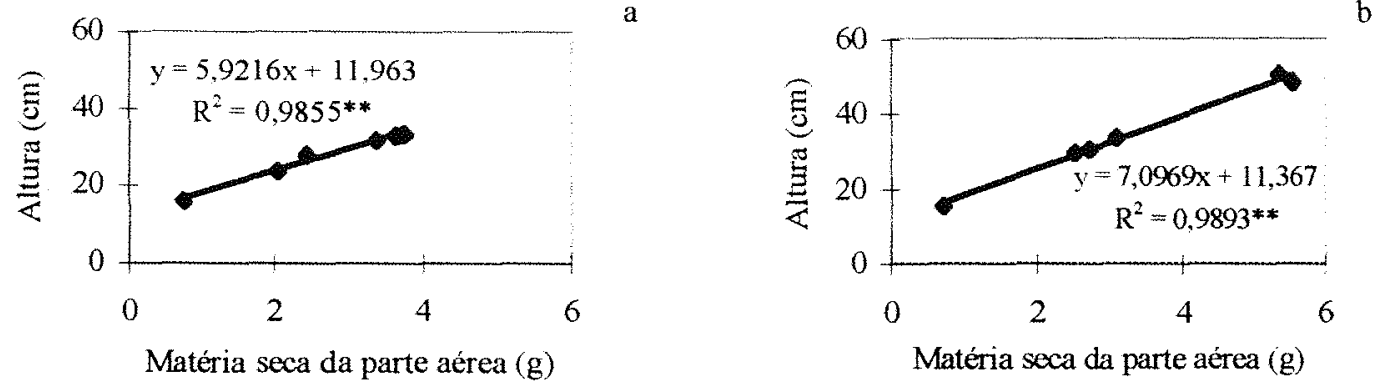

Figura 2. Correlação entre altura e matéria seca da parte aérea para laranja caipira (a) e tangerina cleópatra (b). 

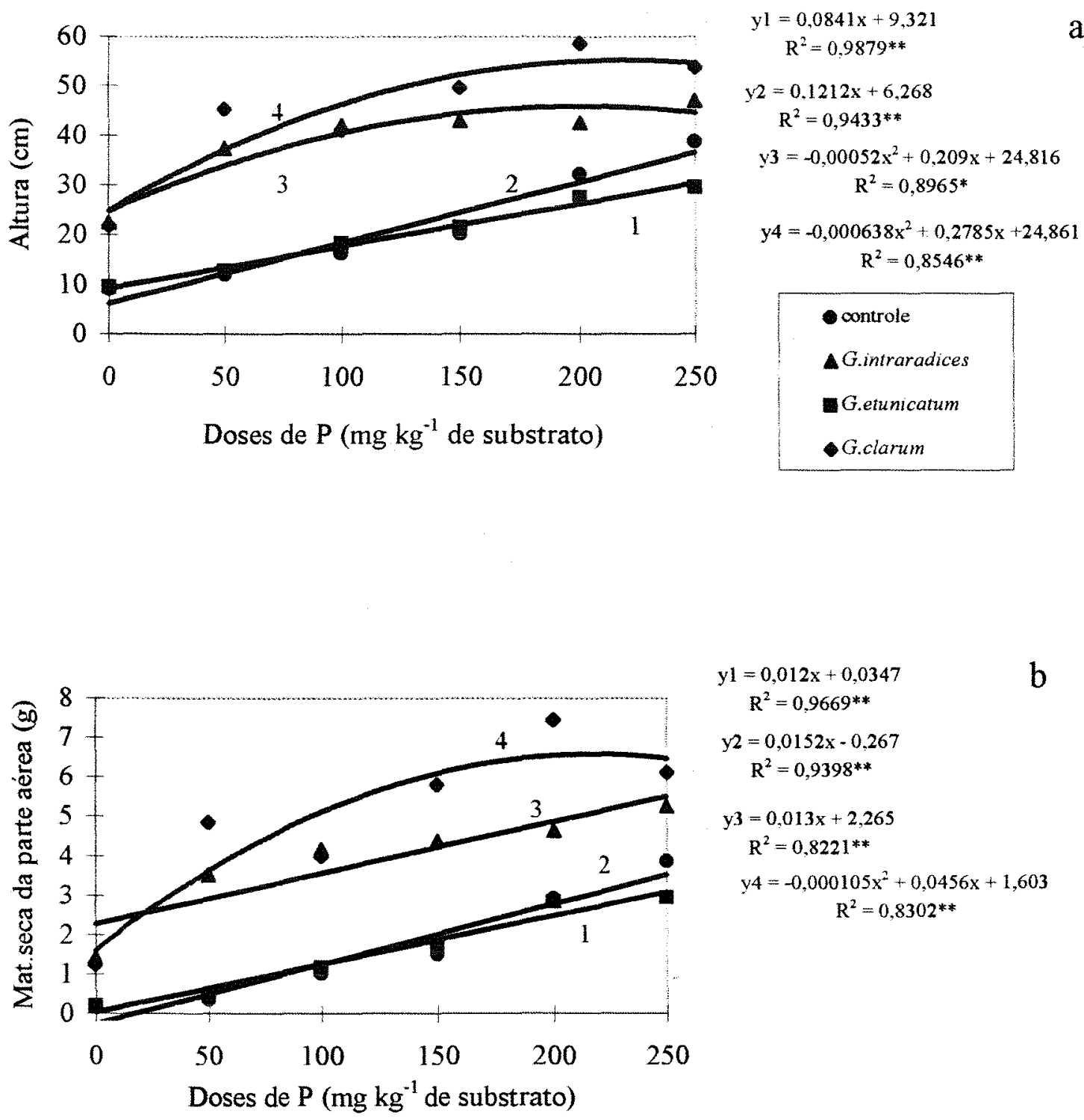
Para a variável diâmetro do caule, verificou-se efeito quadrático de doses de $\mathrm{P}$ (Figura 4), com um pico de resposta na dose de $281 \mathrm{mg} \mathrm{P} \mathrm{kg}^{-1}$ de substrato. As médias para laranja caipira foram significativamente maiores do que para tangerina cleópatra para os fungos $G$. clarum e G. intraradices (Tabela 3).

Este efeito de doses de $\mathrm{P}$ nestas variáveis já era esperado, pelo fato do único nutriente limitante na referida condição experimental ter sido o fósforo, visto que se procurou colocar todos os outros nutrientes em doses não limitantes para o crescimento das plantas. Já em 1842, Justus von Liebig identificou vários elementos químicos necessários ao desenvolvimento vegetativo e estabeleceu a "lei do mínimo", a qual salienta a importância da presença de todos os nutrientes essenciais e a limitação do desenvolvimento vegetal na ausência de um deles (Kiehl, 1993). Diversos autores (Lambais \& Cardoso, 1990; Souza et al, 1991; Fonseca et al, 1994; Melloni et al, 1996a,b, entre outros), em estudos sobre micorriza, constataram correlação positiva e significativa entre matéria seca da parte aérea e $\mathrm{P}$ total absorvido, conforme ocorreu em ambos os porta-enxertos (Figura 5). G. clarum e G. intraradices foram os FMAs que se destacaram nestas variáveis, provavelmente por se apresentarem altamente eficientes na colonização radicular de ambos os porta-enxertos, conforme demonstrado na Tabela 4. G. intraradices apresentou um efeito linear negativo de colonização com o aumento das doses de $\mathrm{P}$ para ambos os porta-enxertos, enquanto se verificou um efeito quadrático para G. clarum nos mesmos portaenxertos (Figura 6). Pelos resultados obtidos, este último parece ser menos sensível ao aumento das doses de $\mathrm{P}$ quando comparado ao $G$. intraradices, já que mesmo em doses elevadas de $\mathrm{P}$ ainda promovia colonização dos hospedeiros. 


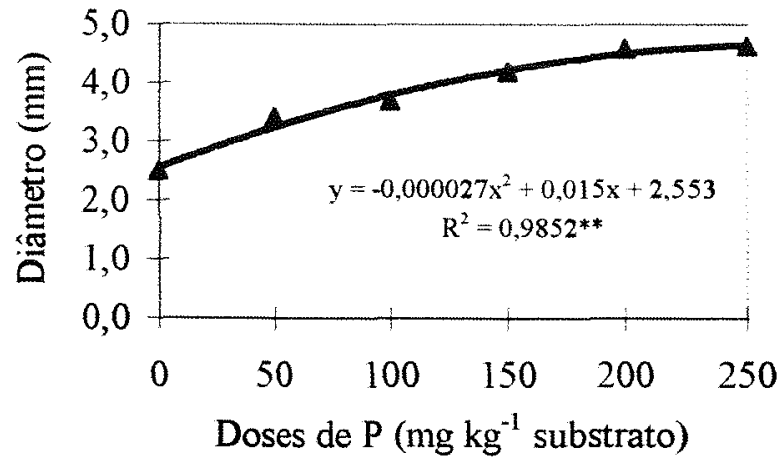

Figura 4. Diâmetro do caule dos porta-enxertos laranja caipira e tangerina cleópatra em função da aplicação de doses crescentes de $\mathrm{P}$ ao substrato (média de 40 repetições). 
Tabela 3. Diâmetro do caule $(\mathrm{mm})$ dos porta-enxertos laranja caipira e tangerina cleópatra, colonizados ou não por FMAs (média de 30 repetições).

\begin{tabular}{lcccc}
\hline Porta-enxertos & Controle & G.intraradices & G.etunicatum & G.clarum \\
\hline Laranja caipira & $3,26 \mathrm{aB}$ & $4,94 \mathrm{aA}$ & $3,21 \mathrm{aB}$ & $5,46 \mathrm{aA}$ \\
Tangerina cleópatra & $2,98 \mathrm{aB}$ & $3,76 \mathrm{bA}$ & $2,99 \mathrm{aB}$ & $4,03 \mathrm{bA}$ \\
\hline
\end{tabular}

Comparam-se letras minúsculas na vertical e maiúsculas na horizontal.

Médias seguidas de letras iguais não diferem entre si, ao nivel de $5 \%$ de significância, pelo teste de Tukey.

Tabela 4. Porcentagem de colonização radicular dos porta-enxertos laranja caipira e tangerina cleópatra, colonizados por FMAs em função da aplicação de doses crescentes de $\mathrm{P}$ (média de 5 repetições).

\begin{tabular}{|c|c|c|c|c|c|c|}
\hline & \multicolumn{2}{|c|}{ G.intraradices } & \multicolumn{2}{|c|}{ G.etunicatum } & \multicolumn{2}{|c|}{ G.clarum } \\
\hline $\begin{array}{c}\text { Doses } \\
\text { de } \mathrm{P}\end{array}$ & $\begin{array}{l}\text { laranja } \\
\text { caipira }\end{array}$ & $\begin{array}{l}\text { tangerina } \\
\text { cleópatra }\end{array}$ & $\begin{array}{l}\text { laranja } \\
\text { caipira }\end{array}$ & $\begin{array}{l}\text { tangerina } \\
\text { cleópatra }\end{array}$ & $\begin{array}{l}\text { laranja } \\
\text { caipira }\end{array}$ & $\begin{array}{l}\text { tangerina } \\
\text { cleópatra }\end{array}$ \\
\hline 0 & $14,2 \mathrm{bB}$ & $27.8 \mathrm{aA}$ & $2.0 \mathrm{aC}$ & $0,2 \mathrm{aB}$ & $35,2 \mathrm{aA}$ & $38,6 \mathrm{aA}$ \\
\hline 50 & $19,9 \mathrm{aA}$ & $20,4 \mathrm{aA}$ & $2,5 \mathrm{aB}$ & $0,1 \mathrm{aB}$ & $22,5 \mathrm{aA}$ & $34,2 \mathrm{aA}$ \\
\hline 100 & $17,5 \mathrm{aB}$ & $14,7 \mathrm{aB}$ & $0,1 \mathrm{aC}$ & $0,0 \mathrm{aC}$ & $39,2 \mathrm{aA}$ & $32,6 \mathrm{aA}$ \\
\hline 150 & $3,4 \mathrm{aB}$ & $4,6 \mathrm{aB}$ & $0,8 \mathrm{aB}$ & $0,0 \mathrm{aC}$ & $32,0 \mathrm{aA}$ & $31,0 \mathrm{aA}$ \\
\hline 200 & $6,6 \mathrm{aB}$ & $0,1 \mathrm{bB}$ & $0,6 \mathrm{aC}$ & $0,0 \mathrm{aB}$ & $26,6 \mathrm{bA}$ & $39,8 \mathrm{aA}$ \\
\hline 250 & $8,7 \mathrm{aA}$ & $1,2 \mathrm{bAB}$ & $0,1 \mathrm{aB}$ & $0,0 \mathrm{aB}$ & $8,9 \mathrm{aA}$ & $4,0 \mathrm{aA}$ \\
\hline
\end{tabular}

Comparam-se letras minúsculas na horizontal entre porta-enxertos para o mesmo FMA e letras maiúsculas entre FMA do mesmo porta-enxerto.

Médias seguidas de letras iguais não diferem entre si, ao nivel de $5 \%$ de significância, pelo teste de Tukey. 


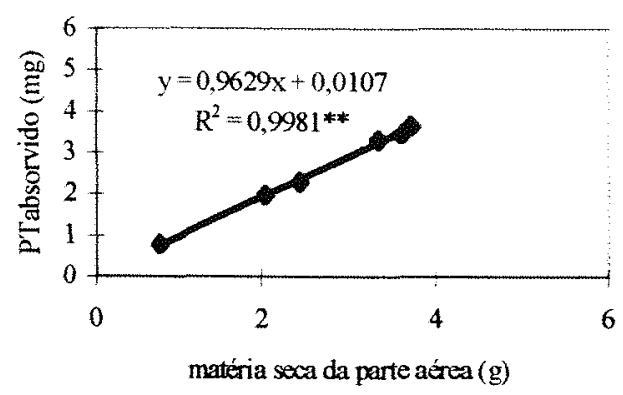

a

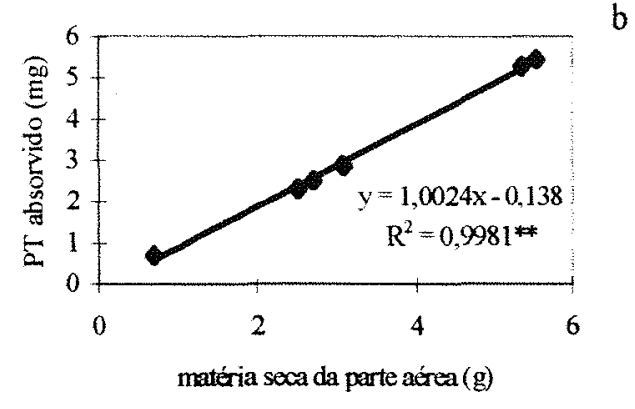

Figura 5. Correlação entre matéria seca da parte aérea e $\mathrm{P}$ total (PT) absorvido por laranja caipira (a) e tangerina cleópatra (b). 


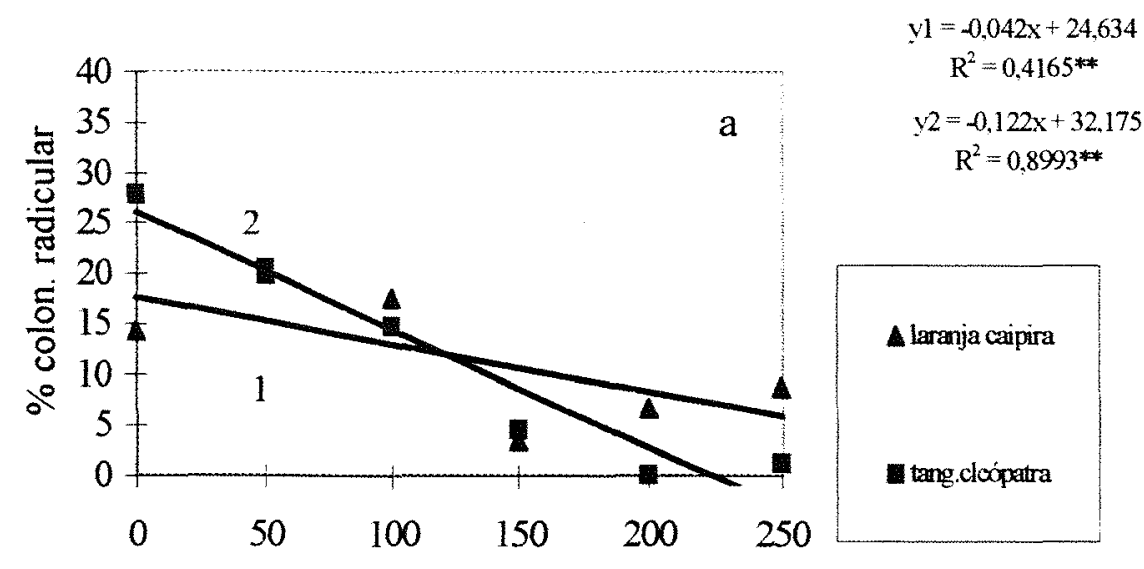

Doses de P ( $\mathrm{mg} \mathrm{kg}^{-1}$ de substrato)

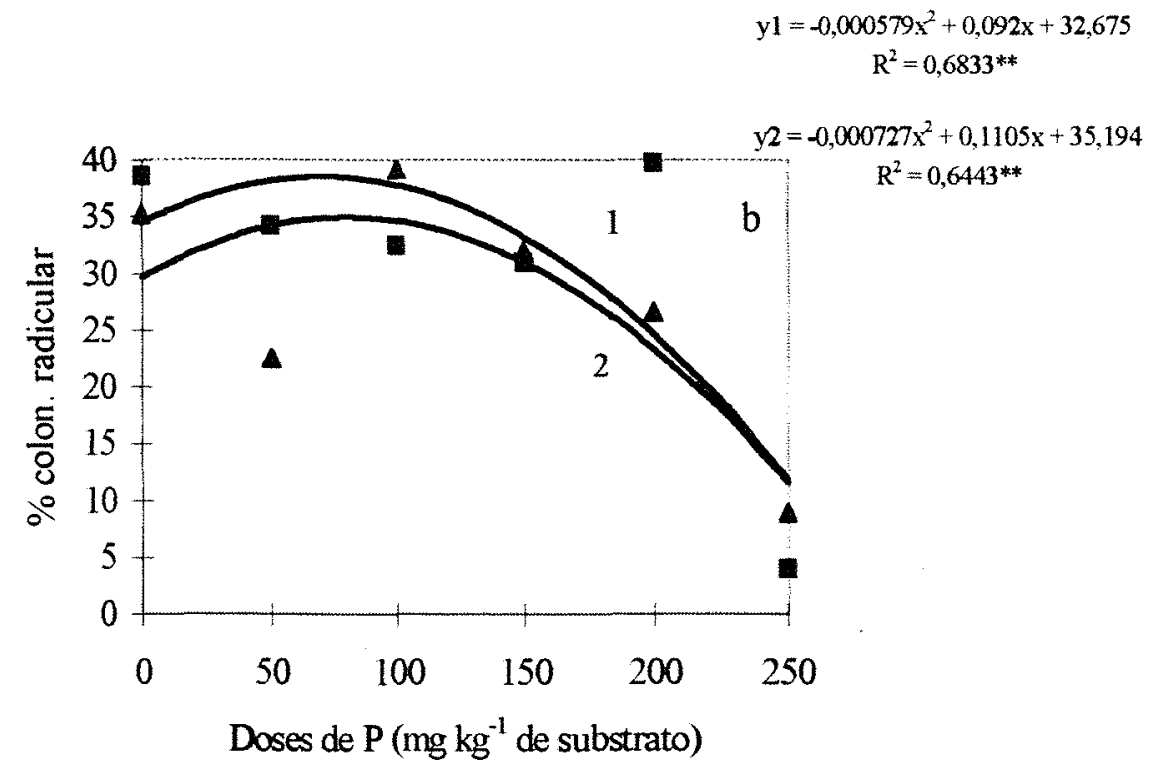

Figura 6. Porcentagem de colonização radicular por G. intraradices (a) e por $G$. clarum (b), nos porta-enxertos laranja caipira e tangerina cleópatra, em função da aplicação de doses crescentes de P ao substrato (média de 5 repetições). 
O efeito negativo de doses de $\mathrm{P}$ na colonização radicular por $G$. intraradices e G. clarum (Figura 6) concorda com os trabalhos de Antunes \& Cardoso (1991), Peng et al. (1993), Miranda \& Harris (1994b) e Melloni et al. (1996a,b). Várias hipóteses podem explicar o fenômeno: à diminuição da exsudação de aminoácidos e açúcares pela raiz, interferindo no processo inicial de desenvolvimento micelial de FMAs (Graham et al, 1981; Miranda \& Harris, 1994a); ao aumento do P foliar com diminuição da permeabilidade da membrana radicular, dificultando a infecção (Jasper et al, 1979; Thomson et al, 1986; Miranda et al, 1989); à variação do fluxo de carboidratos da planta hospedeira ao FMA (Buwalda \& Goh, 1982; Siqueira et al, 1984) ou ao aumento da atividade de endoquitinases e de $\beta-1,3$ endoglucanases, restringindo a colonização interna (Lambais \& Mehdy, 1993; Lambais \& Mehdy, 1995; Lambais \& Mehdy, 1996, no prelo).

Verificou-se correlação significativa negativa entre $\mathrm{P}$ total absorvido pelos dois porta-enxertos e porcentagem de colonização radicular somente para o fungo G. intraradices (Figura 7), confirmando a maior sensibilidade deste fungo ao aumento das doses de $\mathrm{P}$, quando comparado, por exemplo, ao G. clarum. O mesmo não pode ser dito para o fungo G. etunicatum, já que este demonstrou baixa capacidade de colonização radicular de ambos os porta-enxertos (Tabela 4), explicada talvez pela ineficiência enzimática ou morfológica na infeç̧ão radicular.

Nas doses de $\mathrm{P}$ empregadas não se verificou depressão de crescimento de plantas micorrizadas, constatando que as doses empregadas não foram suficientemente elevadas para a ocorrência do fenômeno (Tabela 2 e Figura $3)$. 


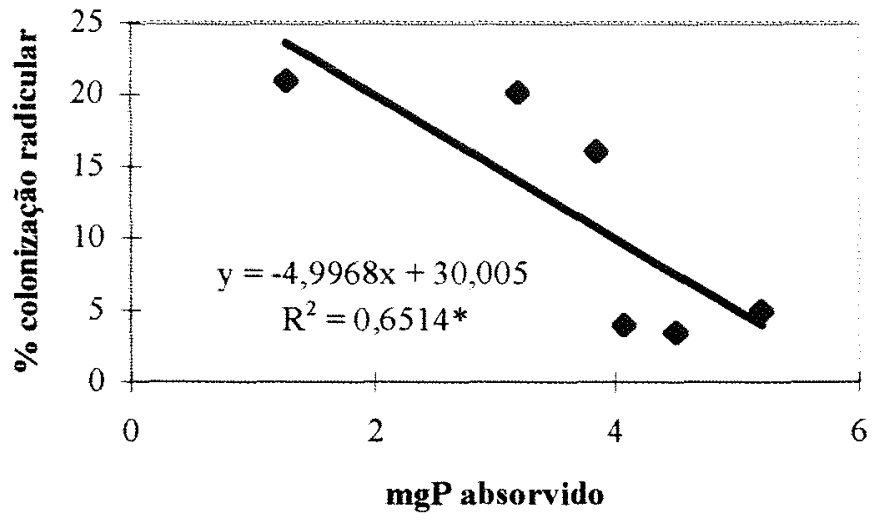

Figura 7. Correlação entre $P$ total absorvido pelos porta-enxertos e $\%$ de colonização radicular por $G$. intraradices. 


\subsection{Absorção de nutrientes pelas plantas cítricas}

Verificaram-se efeitos nas interações duplas: porta-enxerto doses de $\mathrm{P}$ para os nutrientes $\mathrm{N}, \mathrm{P}, \mathrm{Ca}$ e $\mathrm{Mg}$, porta-enxerto - FMAs para os nutrientes $\mathrm{N}, \mathrm{S}, \mathrm{Ca}$ e $\mathrm{Mg}$, e doses de P - FMAs para o nutriente P. O comportamento de absorção de nutrientes por tangerina cléopatra em função das doses aplicadas de $\mathrm{P}$ pode ser expresso por equações lineares, enquanto para laranja caipira verificou-se um efeito quadrático na maioria dos nutrientes avaliados (Figura 8). Destaca-se o acúmulo de maior quantidade absorvida de $\mathrm{P}$ por tangerina cleópatra nas doses mais elevadas (acima de $200 \mathrm{mg} \mathrm{P} \mathrm{kg}^{-1}$ de substrato), o que poderia explicar o maior desenvolvimento vegetal deste portaenxerto, quando comparado à laranja caipira nestas doses (Tabela 2).

Aumentos da quantidade absorvida de nutrientes em função das doses de $\mathrm{P}$ (inclusive $\mathrm{K}$ e $\mathrm{S}$, como demonstrado na Figura 9) poderiam ser explicados pelo aumento da matéria seca da parte aérea (Tabela 2 e Figura 1). Este aumento poderia ser o resultado de 3 fatores, atuando isoladamente ou em conjunto: a) exigência proporcional de nutrientes com o crescimento e a necessidade de manter um equilíbrio nutricional interno para o desenvolvimento celular vegetal normal; b) ao aumento do sistema radicular das plantas ao longo das doses de P, garantindo maior exploração do substrato e maior absorção de nutrientes ou, ainda, c) ao maior desenvolvimento micelial externo total, garantindo maior exploração superficial do substrato, transpondo a zona de depleção nutricional da raiz, como será posteriormente discutido. 


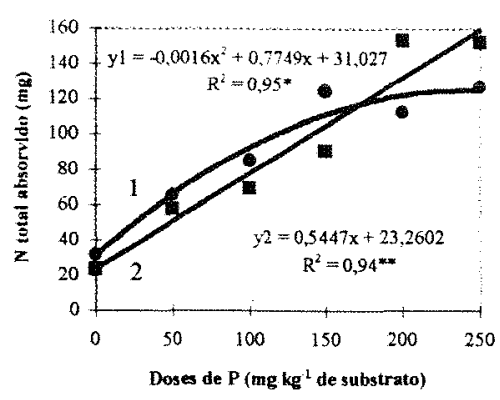

- laranja caipira

- tangerina cleópatra
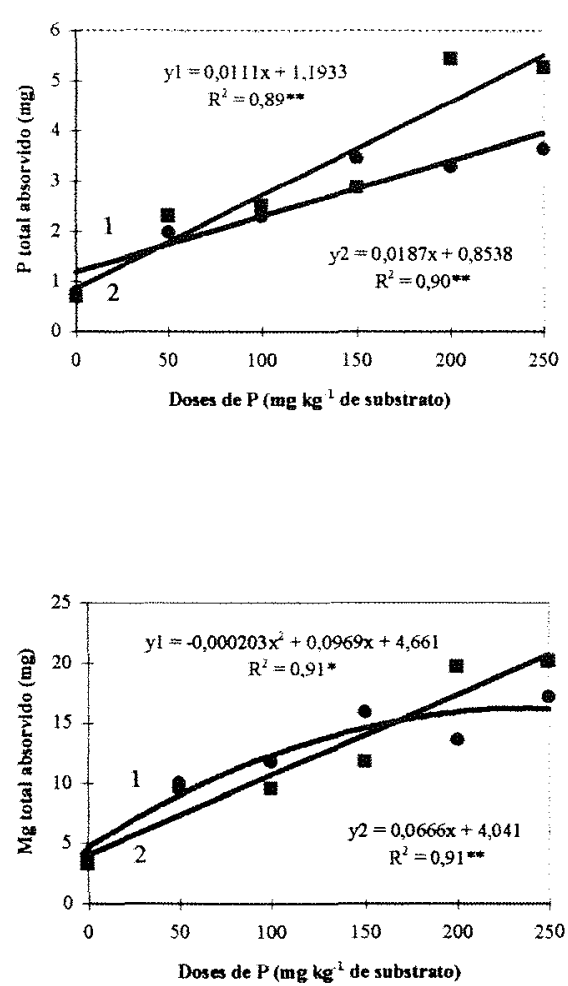

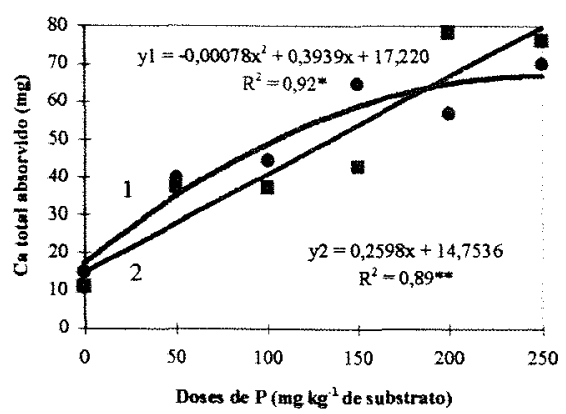

Figura 8. Quantidade total absorvida de N, P, Ca e Mg na parte aérea dos portaenxertos laranja caipira e tangerina cleópatra, em função da aplicação de doses crescentes de $\mathrm{P}$ ao substrato (média de 20 repetições).

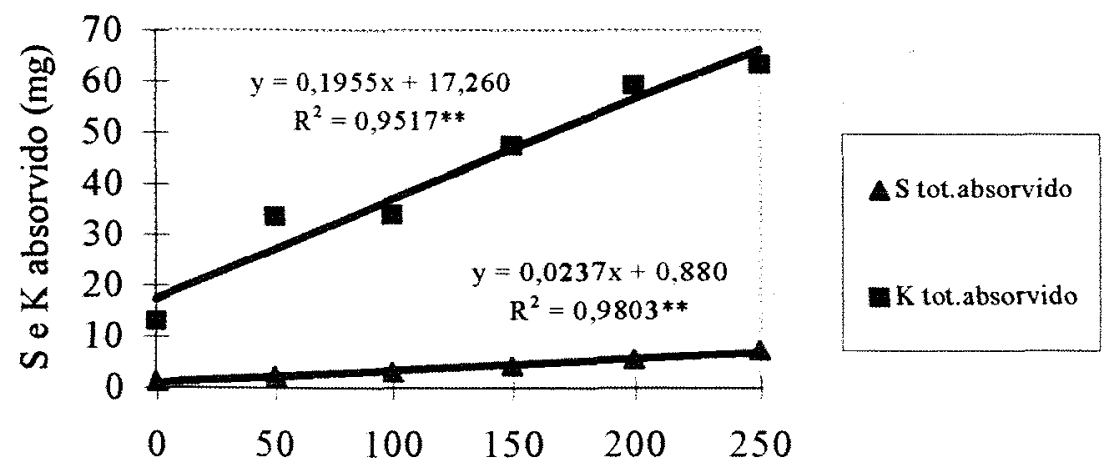

Doses de P ( $\mathrm{mg} \mathrm{kg}^{-1}$ de substrato)

Figura 9. Quantidade total absorvida de $\mathrm{S}$ e $\mathrm{K}$ na parte aérea dos porta-enxertos laranja caipira e tangerina cleópatra, em função da aplicação de doses crescentes de $\mathrm{P}$ ao substrato (média de 40 repetições). 
Quanto ao efeito dos FMAs sobre a composição mineral das plantas, houve resposta no acúmulo de $\mathrm{N}, \mathrm{S}, \mathrm{Ca}$ e $\mathrm{Mg}$ na parte aérea dos portaenxertos, com $G$. clarum e $G$. intraradices novamente se destacando como os FMAs responsáveis pelos maiores valores de absorção (Tabela 5). Verificou-se uma diminuição das quantidades absorvidas de $\mathrm{N}, \mathrm{S}$ e Ca pelo porta-enxerto tangerina cleópatra micorrizado por $G$. clarum, o que não provocou queda significativa na matéria seca da parte aérea destas plantas, mas que poderia ser responsável pelo menor diâmetro do caule observado nestas (Tabela 3), comparado à laranja caipira.

O comportamento da absorção de P pelos FMAs com a aplicação de doses de $\mathrm{P}$ no substrato pode ser representado por equações lineares para os fungos $G$. intraradices e G. etunicatum e equação quadrática para G. clarum, existindo um pico de absorção para este último FMA na dose $229 \mathrm{mg} \mathrm{P} \mathrm{kg}^{-1}$ de substrato. G. intraradices e G. clarum promoveram maior acúmulo deste nutriente com o aumento das doses de $\mathrm{P}$, enquanto $G$. etunicatum não diferiu do controle sem FMA em nenhuma dose aplicada (Figura 10). 

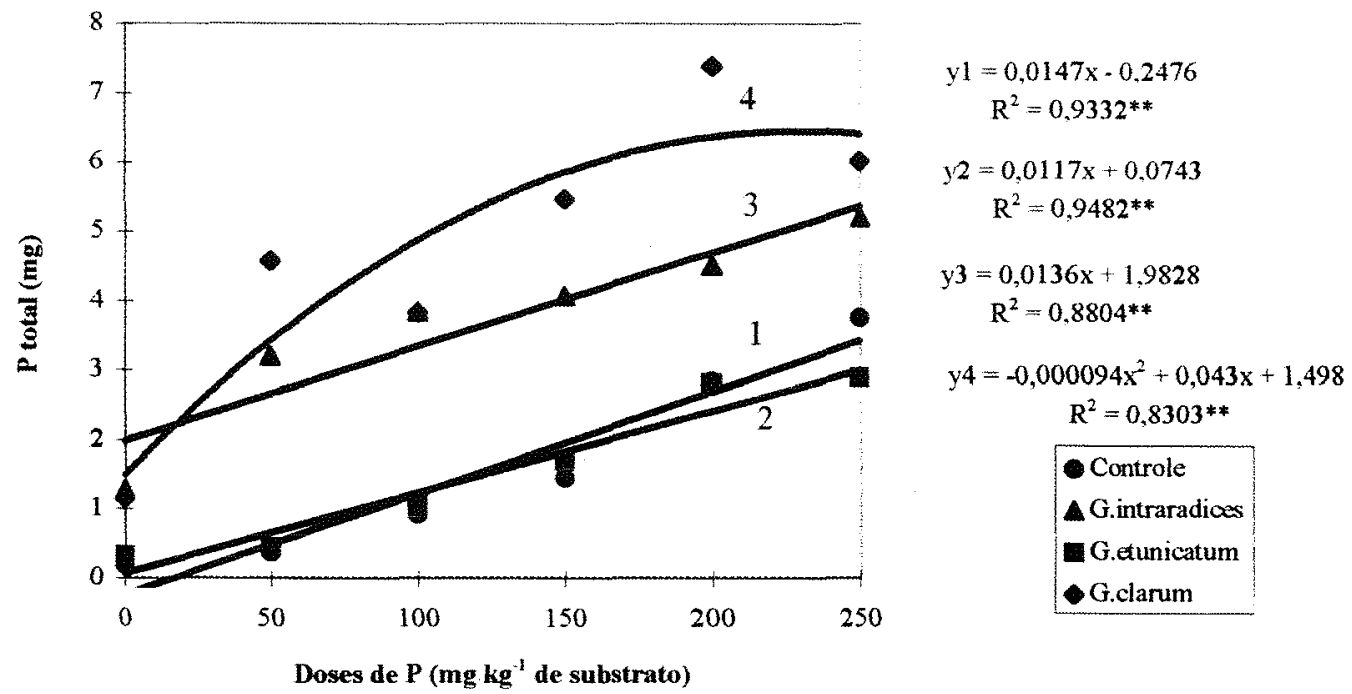

Figura 10. $\mathrm{P}$ total absorvido pelos porta-enxertos laranja caipira e tangerina cleópatra, colonizados ou não por FMAs, em função da aplicação de doses crescentes de $\mathrm{P}$ ao substrato (média de 10 repetições). 
Na Figura 11 estão projetadas curvas de matéria seca da parte aérea e P total absorvido, calculadas pelas equações demontradas nas Figuras $3 \mathrm{e}$ 10 respectivamente, para os diferentes FMAs até a dose $400 \mathrm{mg} \mathrm{P} \mathrm{kg}^{-1}$ de substrato. Enquanto os fungos G. intraradices, G. etunicatum e controle sem FMA apresentaram um comportamento linear positivo de absorção de $\mathrm{P}$ e matéria seca da parte aérea com o aumento das doses de P, G. clarum apresentou efeito quadrático, com diminuição dessas duas variáveis a partir da dose $200 \mathrm{mg} \mathrm{P} \mathrm{kg}^{-1}$ de substrato, igualando-se ao controle sem FMA na dose teórica de $350 \mathrm{mg} \mathrm{P} \mathrm{kg}^{-1}$ de substrato. Portanto, poder-se-ia ocorrer depressão de crescimento vegetal em ambos os porta-enxertos em doses superiores a esta, na presença de G. clarum, como demonstrado por diversos autores utilizando outras espécies cítricas (Antunes \& Cardoso, 1991; Peng et al, 1993).

Há várias hipóteses que procuram explicar este fenômeno e, entre estas, destacam-se: a) produção de toxinas pelo endófito em altas doses de $\mathrm{P}$, que atuariam ao nível de membrana celular alterando o balanço de solutos nas células vegetais, o metabolismo de compostos fenólicos e a produção de ATP; b) alterações da taxa fotossintética e utilização de fotoassimilados decorrentes da variação do balanço de $\mathrm{P}$ nas plantas, podendo levar a um efeito competitivo por $P$ entre a planta e o endófito e a necessidade da produção de carboidratos para evitar que a associação entre planta-FMA se torne parasítica e prejudicial ao desenvolvimento; c) alteração da cinética de absorção de $\mathrm{P}$ em altos níveis do elemento, podendo ocasionar diminuição do influxo do nutriente à planta micorrizada, diminuindo sua disponibilidade para o metabolismo normal do hospedeiro e provocando redução do crescimento; d) alteração do equilíbrio entre micélio extrarradicular ativo e total de FMAs envolvidos na simbiose, interferindo no processo de absorção de nutrientes e na exigência de fotoassimilados, como será posteriormente discutido no presente trabalho. 
Tabela 5. Quantidade acumulada $(\mathrm{mg})$ de $\mathrm{N}, \mathrm{S}, \mathrm{Ca}$ e $\mathrm{Mg}$ na parte aérea dos portaenxertos laranja caipira e tangerina cleópatra, colonizados ou não por FMAs (média de 30 repetições).

\begin{tabular}{lllllllll}
\hline \multirow{2}{*}{ FMAs } & \multicolumn{2}{c}{$\mathrm{N}$ total absorvido } & \multicolumn{2}{c}{$\mathrm{S}$ total absorvido } & $\mathrm{Ca}$ total absorvido & \multicolumn{2}{c}{ Mg total absorvido } \\
\cline { 2 - 8 } & $\begin{array}{l}\text { laranja } \\
\text { caipira }\end{array}$ & $\begin{array}{l}\text { tangerina } \\
\text { cleópatra }\end{array}$ & $\begin{array}{l}\text { laranja } \\
\text { caipira }\end{array}$ & cleópatra & caipira & cleópatra & caipira & cleópatra \\
\hline Controle & $46,65 \mathrm{aC}$ & $64,36 \mathrm{aB}$ & $2,14 \mathrm{aB}$ & $2,70 \mathrm{aBC}$ & $22,95 \mathrm{aC}$ & $31,79 \mathrm{aB}$ & $5,36 \mathrm{aB}$ & $8,28 \mathrm{aB}$ \\
G.intraradices & $121,65 \mathrm{aB}$ & $113,14 \mathrm{aA}$ & $5,73 \mathrm{aA}$ & $4,11 \mathrm{bAB}$ & $65,54 \mathrm{aB}$ & $59,33 \mathrm{aA}$ & $16,91 \mathrm{aA}$ & $15,81 \mathrm{aA}$ \\
G.etunicatum & $42,70 \mathrm{aC}$ & $58,46 \mathrm{aB}$ & $2,12 \mathrm{aB}$ & $2,10 \mathrm{aC}$ & $23,13 \mathrm{aC}$ & $30,21 \mathrm{aB}$ & $5,03 \mathrm{aB}$ & $7,31 \mathrm{aB}$ \\
G.clarum & $154,17 \mathrm{aA}$ & $129,41 \mathrm{bA}$ & $7,22 \mathrm{aA}$ & $4,64 \mathrm{bA}$ & $83,57 \mathrm{aA}$ & $67,57 \mathrm{bA}$ & $21,20 \mathrm{aA}$ & $18,07 \mathrm{aA}$ \\
\hline
\end{tabular}

Comparar letras minúsculas na horizontal e maiúsculas na vertical.

Médias seguidas de letras iguais não diferem entre si, ao nivel de $5 \%$ de significância, pelo teste de Tukey. 

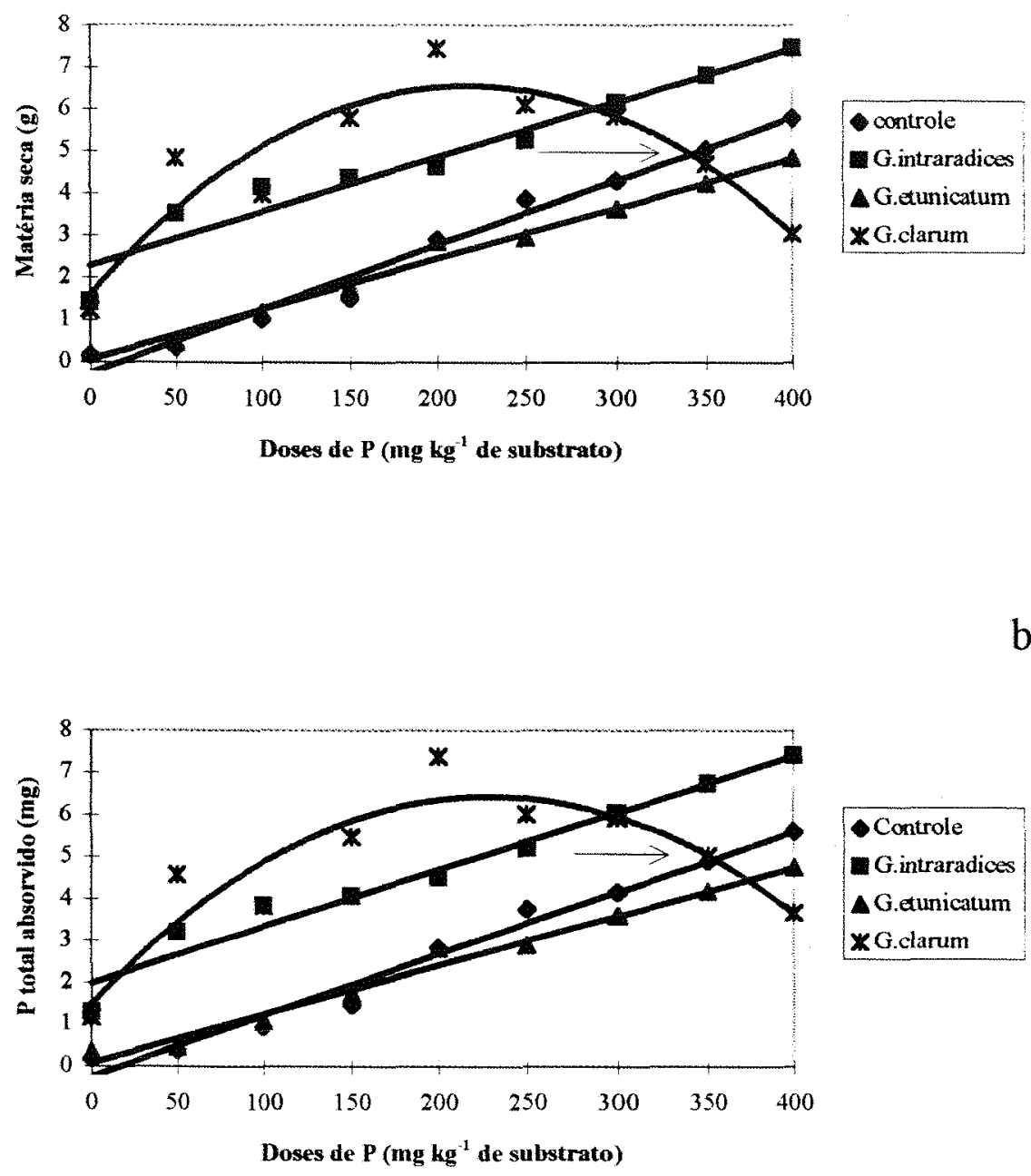

Figura 11. Matéria seca da parte aérea (a) e $P$ total absorvido (b) pelos portaenxertos, em função das doses de $\mathrm{P}$ aplicadas (de 0 a $250 \mathrm{mg} \mathrm{P} \mathrm{kg}^{-1} \mathrm{de}$ substrato) e calculadas ( 300 a $400 \mathrm{mg} \mathrm{P} \mathrm{kg}^{-1}$ de substrato).

* As setas indicam o ponto de cruzamento com o controle, abaixo do qual se encontra a zona de depressão de crescimento. 
Para os micronutrientes $\mathrm{Cu}, \mathrm{Fe}$ e $\mathrm{Mn}$ observaram-se efeitos de doses de $\mathrm{P}$ e FMAs na absorção, com o porta-enxerto tangerina cleópatra diferindo de laranja caipira somente para fungos. Verificou-se efeito significativo linear e positivo de doses de $\mathrm{P}$ na absorção destes micronutrientes (Figura 12), novamente sugerindo relação com o aumento da matéria seca da parte aérea, já observada anteriormente (Tabela 1). G. clarum e $G$. intraradices se destacaram como os FMAs que promoveram maior quantidade absorvida destes nutrientes, em ambos os porta-enxertos, com exceção do elemento $\mathrm{Fe}$, onde somente o $G$. clarum se diferenciou estatisticamente dos demais FMAs (Tabela 6). Na mesma tabela, novamente $G$. etunicatum não diferiu do controle sem FMA em nenhum micronutriente avaliado. Para o micronutriente $\mathrm{Zn}$ total absorvido, verificou-se efeito significativo da interação porta-enxerto e doses de $\mathrm{P}$, com efeito linear $\mathrm{e}$ positivo, sendo que somente na dose $200 \mathrm{mg} \mathrm{P} \mathrm{kg}^{-1}$ de substrato o porta-enxerto tangerina cleópatra apresentou maior acúmulo e diferiu da laranja caipira (Figura 13). G. clarum e G. intraradices se destacaram na absorção deste nutriente, enquanto $G$. etunicatum não diferiu do controle sem FMA (Tabela 6). 

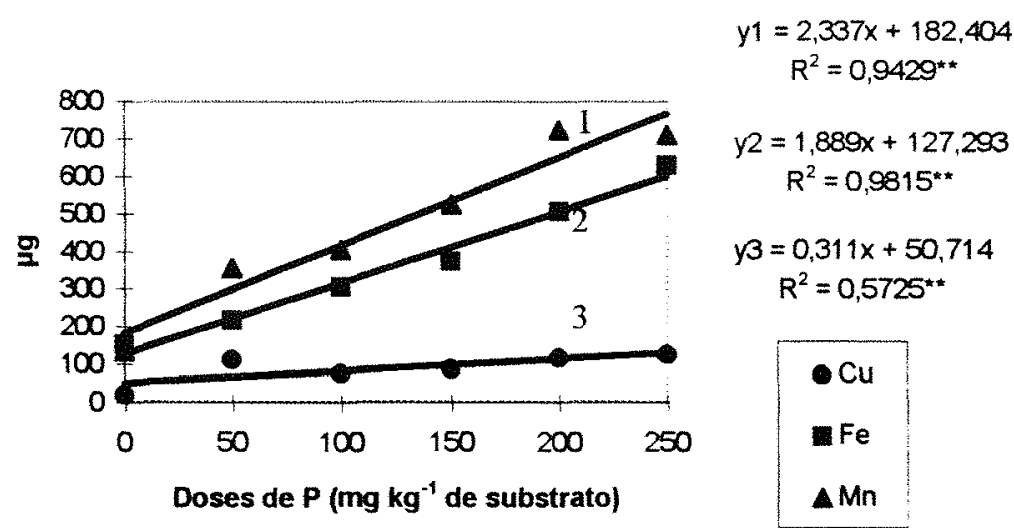

Figura 12. Quantidade total absorvida de $\mathrm{Cu}, \mathrm{Fe}$ e $\mathrm{Mn}$ na parte aérea dos portaenxertos em função da aplicação de doses crescentes de $\mathrm{P}$ ao substrato (média de 40 repetições).

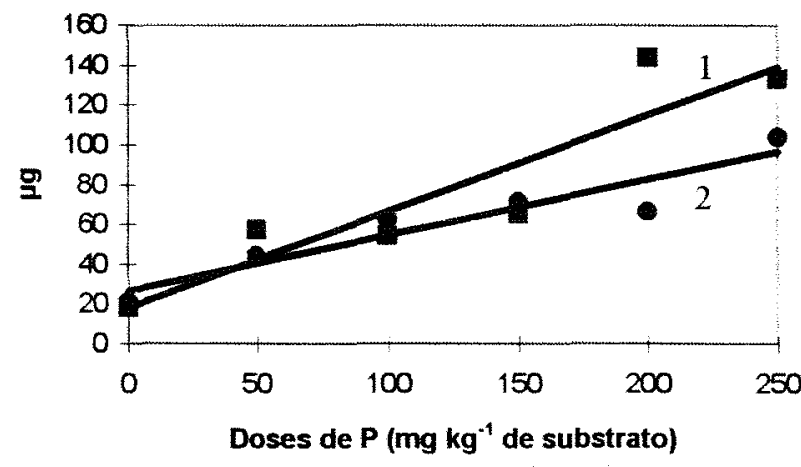

$$
\begin{gathered}
y 1=0,4831 x+18,047 \\
R^{2}=0,8435^{\star \star} \\
y 2=0,2809 x+26,357 \\
R^{2}=0,8897^{\star *}
\end{gathered}
$$

- tangerina cleópatra

- laranja caipira

Figura 13. Quantidade total absorvida de $\mathrm{Zn}$ na parte aérea dos porta-enxertos laranja caipira e tangerina cleópatra, em função da aplicação de doses crescentes de $\mathrm{P}$ ao substrato (média de 20 repetições). 
Tabela 6. Quantidade acumulada ( $\mu \mathrm{g})$ de $\mathrm{Cu}, \mathrm{Fe}, \mathrm{Mn}$ e $\mathrm{Zn}$ na parte aérea dos porta-enxertos (média de 60 repetições).

\begin{tabular}{lcccc}
\hline FMAs & $\mathrm{Cu}$ & $\mathrm{Fe}$ & $\mathrm{Mn}$ & $\mathrm{Zn}$ \\
\hline Controle & $37 \mathrm{~b}$ & $345 \mathrm{~b}$ & $280 \mathrm{~b}$ & $44 \mathrm{~b}$ \\
G.intraradices & $138 \mathrm{a}$ & $338 \mathrm{~b}$ & $651 \mathrm{a}$ & $96 \mathrm{a}$ \\
G.etunicatum & $36 \mathrm{~b}$ & $269 \mathrm{~b}$ & $283 \mathrm{~b}$ & $33 \mathrm{~b}$ \\
G.clarum & $146 \mathrm{a}$ & $502 \mathrm{a}$ & $684 \mathrm{a}$ & $107 \mathrm{a}$ \\
\hline
\end{tabular}

Comparar letras na vertical.

Médias seguidas de letras iguais não diferem entre si, ao nivel de $5 \%$ de significância, pelo teste de Tukey. 


\subsection{Micélio extrarradicular ativo (MEA) e total (MET) de FMAs}

Verificou-se efeito de tripla interação (porta-enxerto - doses de $\mathrm{P}$ - métodos de avaliação da atividade) na determinação do comprimento de MEA, a $5 \%$ de significância. Laranja caipira mostrou ser o porta-enxerto com o maior comprimento de MEA, principalmente em doses iguais ou inferiores a $100 \mathrm{mg}$ $\mathrm{P} \mathrm{kg}^{-1}$ de substrato, quando comparado à tangerina cleópatra, independente do método empregado (Figura 14), bem como do FMA (Figura 15), sugerindo um cuidado adicional em estudos interligados, visto à influência do hospedeiro nesta variável. 


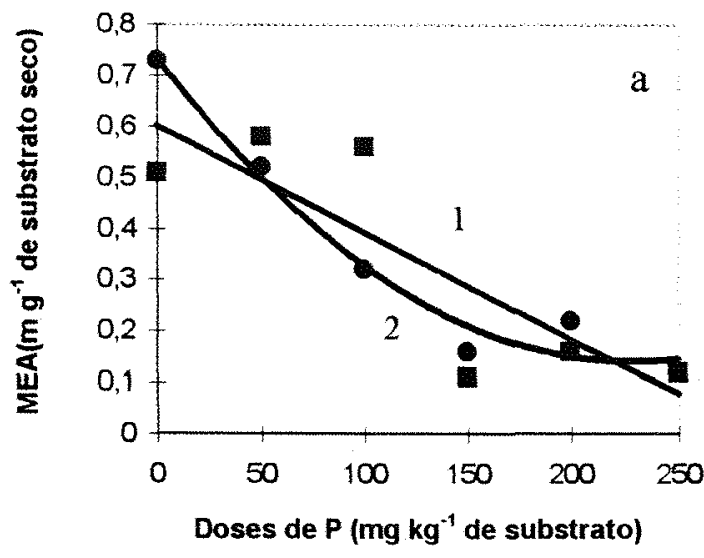

$y 1=-0,0021 x+0,602$
$R^{2}=0,7178^{* *}$

$y 2=0,000011 x^{2}-0,0051 x+0,732$

$R^{2}=0,9726^{* *}$

- FDA

- INT

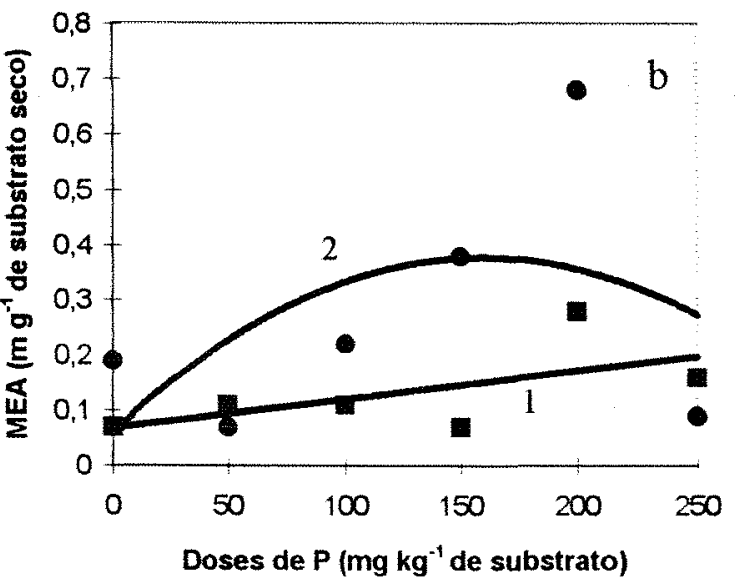

$y_{1}=$ n.s.

$y 2=-0,0000128 x^{2}+0,00407 x-0,055$

$R^{2}=0,2655^{* *}$

Figura 14. Comprimento de MEA de FMAs para laranja caipira (a) e tangerina cleópatra (b) determinado por diferentes métodos de avaliação, em função da aplicação de doses crescentes de P ao substrato (média de 20 repetições). 

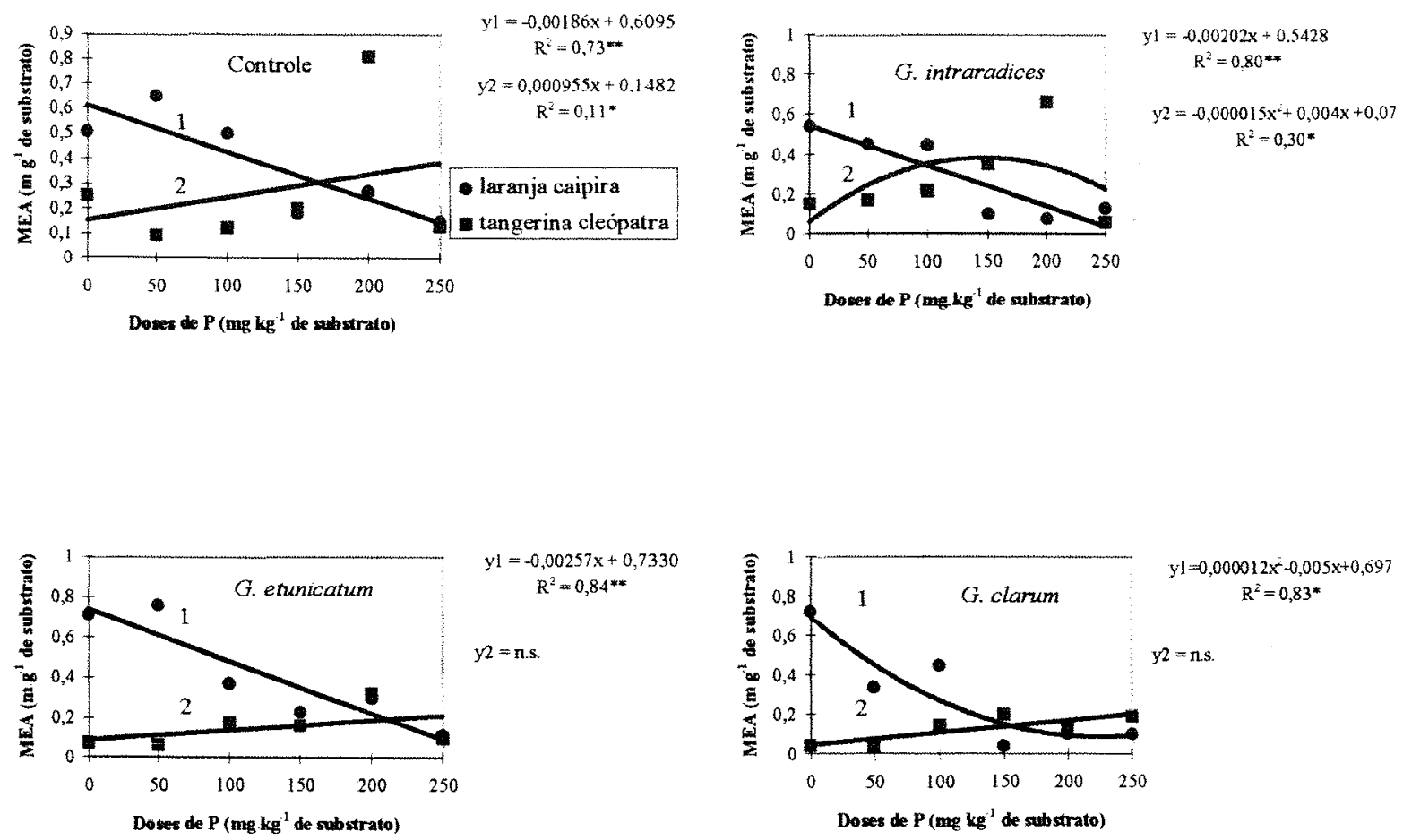

Figura 15. Comprimento de MEA de FMAs nos porta-enxertos laranja caipira e tangerina cleópatra, em função da aplicação de doses crescentes de $\mathrm{P}$ (média de 10 repetições). 
Para o método INT verificou-se um efeito linear em função do aumento das doses de $\mathrm{P}$, enquanto que para o método FDA o efeito pode ser representado por equações quadráticas, tanto em laranja caipira quanto em tangerina cleópatra. Com isto, verifica-se um efeito mais pronunciado das doses de $\mathrm{P}$ para o método INT e a existência de faixas de $\mathrm{P}$ onde o método FDA apresentaria maior eficiência na indicação de atividade micelial, que no presente trabalho ocorreu em doses superiores a $150 \mathrm{mg} \mathrm{kg}^{-1}$ de substrato, para tangerina cleópatra (Figura 14). Como ambos os métodos empregados para determinação da atividade micelial são enzimáticos e cada método atua em um complexo enzimático diferente, os resultados podem ser controvertidos e o efeito de altas doses de $\mathrm{P}$ pode ser diferenciado, como de fato se observou, concordando com Hamel et al. (1990). Segundo Beever \& Burns (1980), altas doses de P podem inibir o ciclo de Krebs, e como o INT é reduzido por enzimas presentes neste ciclo, o método tenderia a indicar menor quantidade de MEA quando empregado nestas doses de $\mathrm{P}$, quando comparado ao método FDA.

Não houve efeito significativo de espécies de FMAs na variável comprimento de MEA, mas para todas verificou-se um efeito positivo do aumento das doses de $\mathrm{P}$ nesta variável, quando associados ao porta-enxerto tangerina cleópatra (Figura 15). Apesar da suscetibilidade da planta à micorrização ser controlada geneticamente, a diferença de comportamento verificada entre os porta-enxertos seria, provavelmente, devido a fatores morfológicos e/ou físiológicos ligados à facilidade com que ocorreria a absorção de $\mathrm{P}$ e outros nutrientes pela raiz, à exigência de $\mathrm{P}$ pelo hospedeiro, à morfologia radicular ligada à penetração do fungo, à produção e liberação de exsudatos radiculares responsáveis pela atração e formação da comunidade biológica na micorrizosfera e à espécie ou ao isolado de FMA utilizado, cujo grau de compatibilidade fungo- 
planta parece estar ligado a mecanismos de reconhecimento entre os simbiontes (Silveira, 1992).

Foram encontrados valores consideráveis de comprimento de MEA em substratos sem infestação com FMAs (controle), sugerindo a existência de fungos sapróbios, oriundos provavelmente do inóculo original ou de contaminação natural (poeira, respingos de água, ventilação, entre outros), já que o substrato foi previamente autoclavado, destruindo todas as formas vivas presentes inicialmente no substrato natural. Portanto, em estudos de desenvolvimento micelial de FMA, recomendar-se-ia, além de cuidados básicos de limpeza de casa-de-vegetação e controle de insetos, utilizar um inóculo de pureza conhecida, sem contaminação, talvez unicamente de esporos isolados do FMA de interesse. Sylvia (1988) comparou os métodos de infestação de substrato por esporos e por solo com propágulos, e encontrou, além de maior porcentagem de colonização radicular, tendência de maior comprimento de micélio extrarradicular por comprimento de raiz. A autoclavagem destruiria os micélios ativos, mas permitiria ainda, grande quantidade de micélio inativo ou morto no substrato (Sylvia, 1988), podendo comprometer os resultados obtidos, pela dificuldade principalmente de homogeneização e montagem das parcelas experimentais.

É praticamente impossível diferenciar visualmente micélios de FMAs de outros não micorrizicos, o que dificulta ainda mais o trabalho de quantificação (Abbott et al, 1984). O que a maioria dos autores propõe é descontar a quantidade de MET encontrada nos substratos-controle da quantidade avaliada nos substratos infestados com FMAs, considerando não ocorrer interações entre micélios fúngicos diversos ou competições (Sylvia, 1992). Neste experimento não se fizeram tais cálculos pelo fato de se encontrar grande quantidade de MET nos substratos-controle, em praticamente todas as doses de $\mathrm{P}$ 
e porta-enxertos testados, e não se verificar diferença significativa entre os FMAs avaliados. Não se subtraiu o comprimento de MEA do FMA daquele apresentado pelo controle, pelo fato de não se conhecerem as diferenças de comportamento entre os mesmos numa mesma condição ambiental. A Figura 15 indica que o comprimento de MEA de fungos sapróbios é maior, embora não estatisticamente diferente, em substrato-controle (principalmente associados à tangerina cleópatra) do que em substrato infestado com FMAs, sugerindo possível inibição de desenvolvimento micelial dos primeiros na presença dos FMAs e impossibilitando a subtração dos valores. Este resultado vem confirmar que a micorrizosfera difere profundamente da rizosfera de plantas não micorrizadas, como já discutido por Silveira (1992), e que a única maneira realmente confiável para se estimar o comprimento de MEA ou MET seja através da técnica de imunofluorescência, aliando antissoros específicos para cada FMA com fluorescência (Kough et al, 1983; Wilson et al, 1983). Todos os FMAs utilizados apresentaram um comportamento semelhante de comprimento de MEA ao longo das doses de $\mathrm{P}$ e porta-enxertos, como pôde ser visto na Figura 15. Tais comprimentos apresentados de MEA se referem à amostragem geral de substrato contido em cada vaso, não limitada às proximidades radiculares, onde aqui seriam maiores (mais funcionais) por se tratar de simbiontes obrigatórios, conforme discutido por Sylvia (1988). Esta diminuição do comprimento de MEA ao longo das doses de $\mathrm{P}$ poderia estar associada aos nutrientes acrescentados com o $\mathrm{P}$, na forma de $\mathrm{KH}_{2} \mathrm{PO}_{4}$ e $\mathrm{NaH}_{2} \mathrm{PO}_{4} \cdot \mathrm{H}_{2} \mathrm{O}$, no referido experimento. Segundo Silva et al.(1991), o $\mathrm{K}^{+}$exerceria um efeito inibitório no crescimento micelial, pelo fato de promover grande absorção e concentração intracelular de $\mathrm{P}$ (e também $\mathrm{K}$ ), podendo atingir níveis tóxicos. Dever-se-ia, então, dar importância não somente ao elemento $P$, mas aos outros íons acompanhantes, já que estes poderiam exercer efeito na fase de desenvolvimento inicial fúngico, antes da penetração e colonização radicular. 
Encontraram-se correlações positivas e significativas a $5 \%$ entre comprimento de MEA de $G$. intraradices e G. etunicatum e porcentagem de colonização radicular em laranja caipira, conforme Figura 16. Este fato provavelmente indicaria uma extensão das estruturas fúngicas ativas presentes no interior de uma raiz considerada altamente colonizada, concordando com Sylvia (1988), apesar da baixa eficiência do último FMA. Teoricamente, seria de se esperar este comportamento, já que havendo maior comprimento de micélio extrarradicular ativo explorando o solo, deveria conjuntamente haver maior quantidade de estruturas internas como micélios e arbúsculos para que se efetuassem as trocas nutricionais entre os simbiontes. Para o porta-enxerto tangerina cleópatra e para o fungo G. clarum não se encontraram correlações significativas para estas variáveis.

Uma correlação negativa significativa foi encontrada entre comprimento de MEA de FMAs (métodos FDA e INT) e P total absorvido em laranja caipira (Figura 17), contrariando os resultados obtidos em experimento anterior utilizando limão cravo (Melloni et al, 1996b) e trevo (Schubert et al, 1987). Esta poderia ser uma resposta da própria planta ao desenvolvimento micelial de FMA, já que a mesma estaria absorvendo $P$ pela raiz, independentemente da presença do fungo, e não haveria a necessidade de dispender energia para que se mantivessem as hifas ativas do fungo, responsáveis pela absorção deste nutriente. Para tangerina cleópatra, foi encontrada correlação positiva e significativa entre comprimento de MEA (método INT) e $\mathrm{P}$ total absorvido (Figura 18), concordando com os autores acima. Isto comprovaria que a absorção de $\mathrm{P}$ pelos FMAs é um processo ativo, próprio de MEA, com dispêndio de energia pelo hospedeiro (Beever \& Burns, 1980; Cooper \& Tinker, 1981; Sylvia, 1992). Como a quantidade de $\mathrm{P}$ absorvida foi diretamente proporcional à quantidade de $\mathrm{P}$ aplicada ao substrato (Figura 11), poderia-se esperar tendência de 
efeito depressivo de altas doses de P (Tabela 2) neste porta-enxerto (tangerina cleópatra), já que haveria maior comprimento de MEA (Figuras 14 e 15) e maior gasto de energia pelo hospedeiro para manter a simbiose, o que não ocorreu. Ingham \& Klein (1984) encontraram correlação positiva entre comprimento de MEA e respiração (liberação de $\mathrm{CO}_{2}$ ) em alguns fungos do solo, comprovando a necessidade de energia para que este processo ocorra e o envolvimento dos mesmos no ciclo do carbono.

Mais uma vez se evidencia o comportamento diferenciado dos hospedeiros em função das espécies de FMAs e doses de P, dificultando a generalização e a compreensão de todo o processo envolvido na simbiose. 

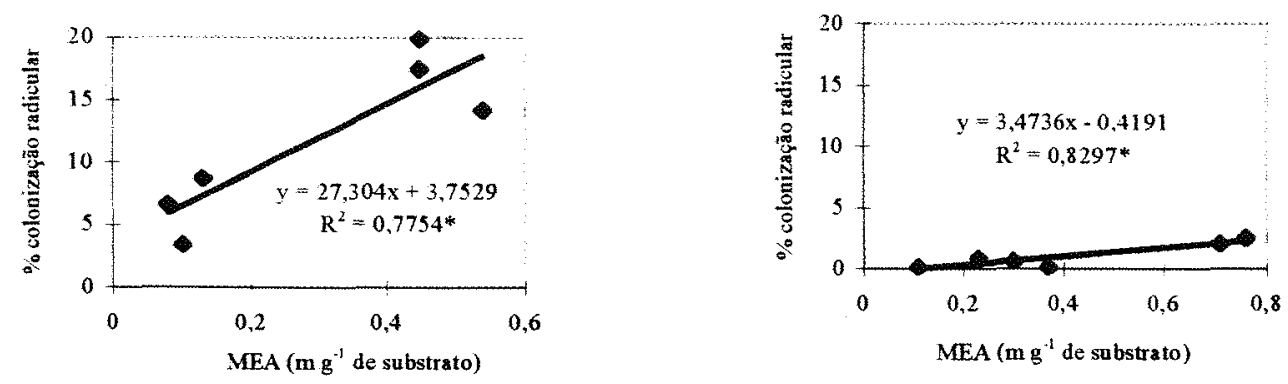

Figura 16. Correlação entre comprimento de MEA de $G$. intraradices (a) ou $G$. etunicatum (b) e porcentagem de colonização radicular, em laranja caipira.
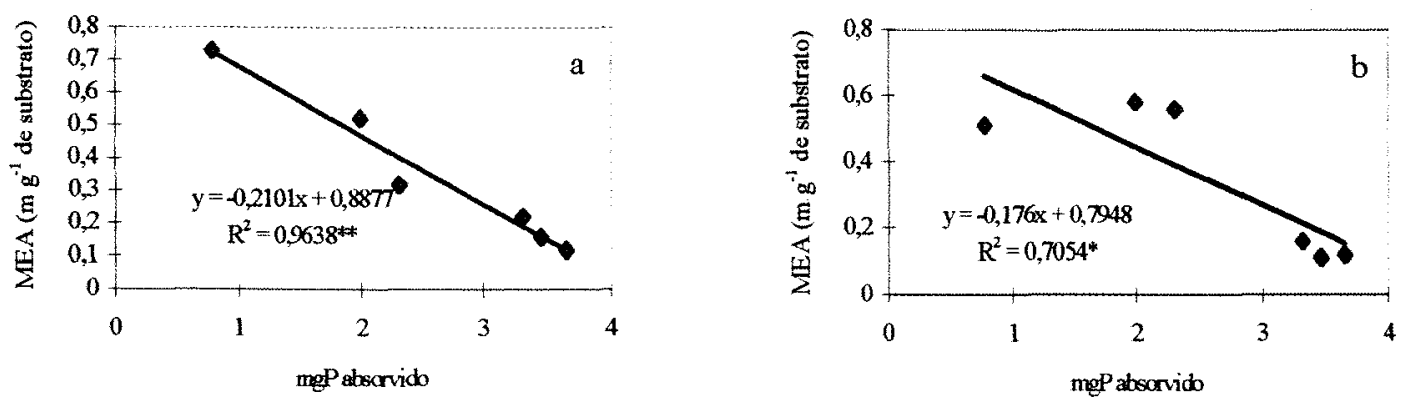

Figura 17. Correlação entre comprimento de MEA pelo método FDA (a) ou INT (b) e P total absorvido, em laranja caipira.

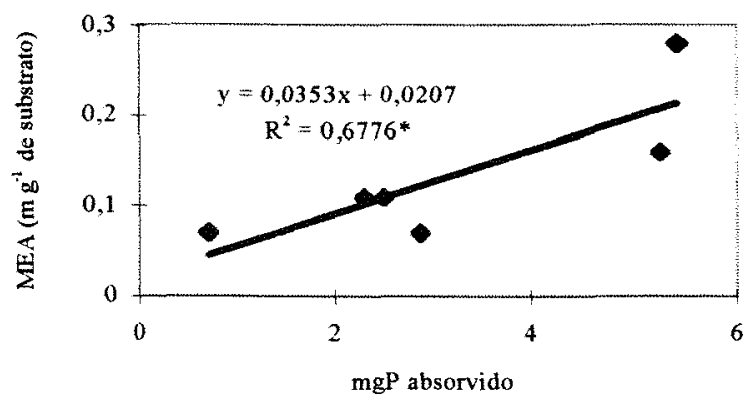

Figura 18. Correlação entre comprimento de MEA de todos os FMAs pelo método INT e P total absorvido, em tangerina cleópatra. 
Para o comprimento de MET, verificou-se efeito da interação dupla porta-enxerto e doses de $\mathrm{P}$ nesta variável, a $5 \%$ de significância. Não se verificou diferença estatística significativa de comprimento de MET de FMAs em doses de $\mathrm{P}$ iguais e menores que $150 \mathrm{mg} \mathrm{kg}^{-1}$ de substrato para ambos os portaenxertos, mas em doses superiores, tangerina cleópatra superou significativamente a laranja caipira (Figura 19). Verificou-se um efeito positivo e crescente de doses de $\mathrm{P}$ no comprimento de MET de FMAs para tangerina cleópatra, representado por uma equação linear, enquanto que para laranja caipira não houve ajuste significativo, ou seja, o MET não variou com a dose de $\mathrm{P}$ aplicada ao substrato.

Esta observação contraria os resultados obtidos por Abbott \& Robson (1985), Miller et al. (1987), Miranda et al. (1989), Miranda \& Harris (1994a,b), entre outros, que encontraram redução do crescimento micelial extrarradicular paralela ao aumento da concentração de P na planta, e concorda com os obtidos por Crush (1976) em leguminosas, Cardoso-Filho (1994) em milho e Melloni et al.(1996b) em limão cravo. Abbott et al.(1984) discutiram que o P poderia, ainda, atuar não diretamente no crescimento micelial, mas no aumento da densidade radicular, reduzindo a distância que o micélio deveria crescer para interceptar a raiz do hospedeiro. Estes resultados sugerem que plantas com maior quantidade de $\mathrm{P}$ absorvida e acumulada (aquelas mais propensas à depressão de crescimento quando micorrizadas) poderiam gastar mais fotoassimilados para a formação de maior comprimento de MET, enquanto proporcionalmente, uma pequena parte deste estaria ativa e envolvida no processo de absorção desse nutriente.

Além do $\mathrm{P}$ total absorvido (Figura 17), observou-se correlação negativa significativa entre totais absorvidos de $\mathrm{N}$, Ca e Mg e comprimento de MEA para laranja caipira (Figura 21), enquanto correlação positiva significativa entre os mesmos macronutrientes e comprimento de MET na tangerina cleópatra 
(Figuras 20 e 21). Esta última correlação indica que podem existir outros mecanismos de absorção e translocação de nutrientes que não pelo MEA, como já discutido por Schubert et al. (1987) e Miranda et al. (1989). Esses primeiros autores discutiram que a translocação de P ocorreria principalmente pela corrente citoplasmática (Harley \& Smith, 1983; Sylvia, 1988), mas que poderia se dar também juntamente com o fluxo de água e solutos, de importância secundária.

Os dados sugerem duas hipóteses: a) a absorção destes nutrientes poderia não ser promovida pelo MEA e sim pelo MET (compreendendo o micélio extrarradicular inativo) ou b) a alta quantidade absorvida de nutrientes pela raiz ou pelo micélio extrarradicular inativo promoveria um efeito "feed-back" negativo, reduzindo o comprimento de MEA e evitando o desvio desnecessário de fotoassimilados do hospedeiro ao FMA. Miranda et al. (1989) e Jakobsen et al. (1994) discutiram, neste sentido, que uma alta quantidade de $\mathrm{P}$ absorvida pelo MEA (e concentrada na planta) poderia diminuir a absorção radicular, ou a presença desta absorção radicular poderia impedir o funcionamento ótimo do MEA pela competição por $\mathrm{P}$ ou interações com microrganismos da rizosfera.

$\mathrm{O}$ fato de se verificar a existência de correlações positivas entre $\mathrm{P}$ absorvido e MEA (Figura 18) e entre macronutrientes absorvidos ( $\mathrm{P}, \mathrm{N}, \mathrm{Ca}$ e $\mathrm{Mg}$ ) e MET de FMAs (Figuras 20 e 21) somente em tangerina cleópatra sugere a hipótese de que seja o porta-enxerto com maior necessidade da simbiose (maior dependência micorrízica) para esta absorção, diferente da laranja caipira que seria capaz de absorvê-los pelo próprio sistema radicular. Segundo Oliveira \& Jesus (1987), tangerina cleópatra possui um sistema radicular com dominância apical e uma baixa relação de massa entre raiz e parte aérea, confirmando ser uma planta mais micotrófica, o que foi comprovado no presente trabalho .

Não se encontrou, neste experimento, correlação significativa entre comprimento de MEA e MET de FMAs em nenhum porta-enxerto utilizado, 
contrariando Sylvia (1988), e indicando que a atividade não depende do crescimento micelial total e este não depende da atividade.

Torna-se importante, ainda, questionar a reprodutibilidade dos resultados obtidos, já que se empregaram condições especificas de instalação e condução do experimento em casa-de-vegetação e laboratório. Seriam, então, necessários, outros estudos envolvendo a questão de depressão de crescimento em espécies cítricas, restringindo, se possivel, o hospedeiro, os FMAs de interesse e as doses de $\mathrm{P}$ mais próximas daquelas em que se observaram tendência da ocorrência do fenômeno.

A Figura 22 apresenta uma pequena amostra das observações de MET e MEAs, indicando, como já comentado, a facilidade de identificação de micélio ativo pelo método FDA em relação ao método INT. 


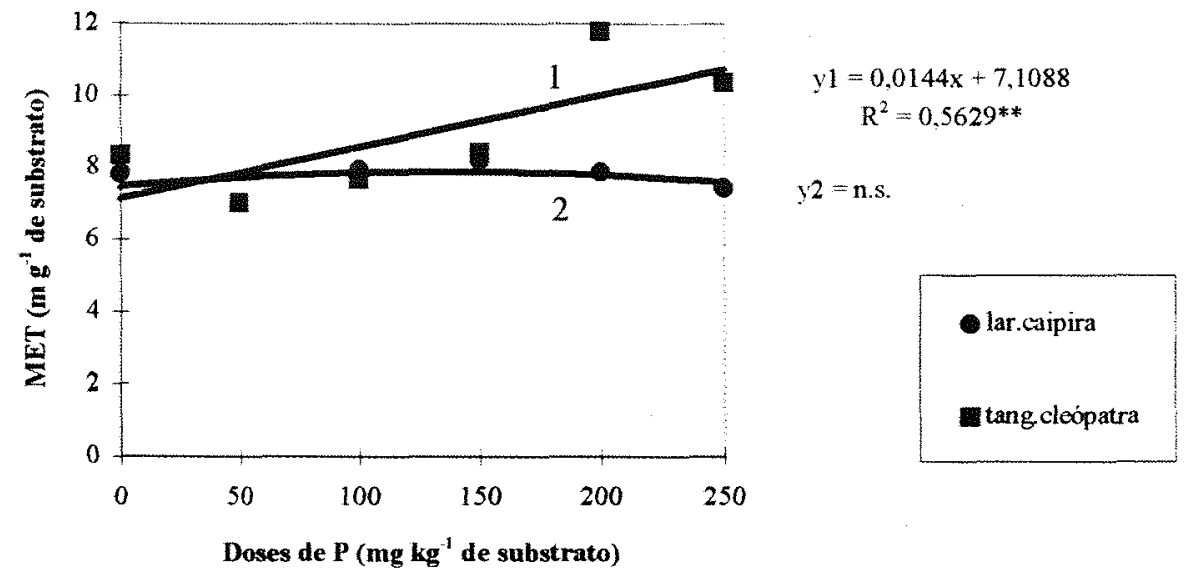

Figura 19. Comprimento de MET de FMAs para os porta-enxertos laranja caipira e tangerina cleópatra, em função da aplicação de doses crescentes de $\mathrm{P}$ (média de 40 repetições).

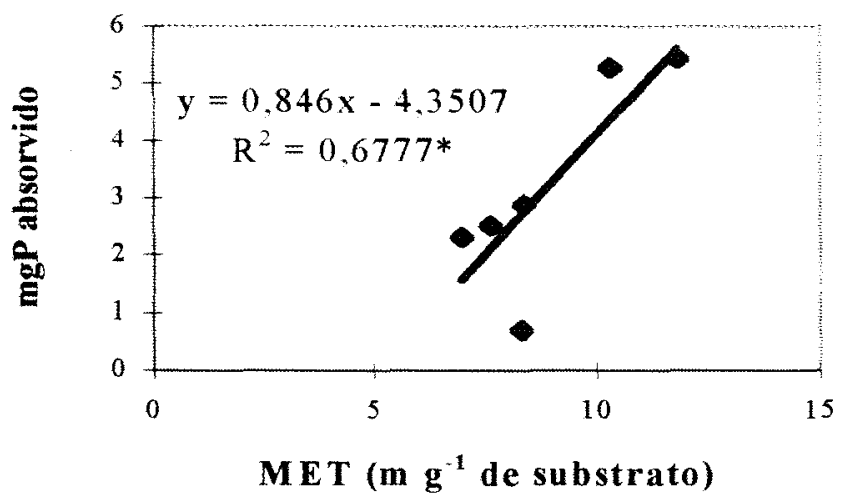

Figura 20. Correlação entre P total absorvido e comprimento de MET de FMAs em tangerina cleópatra. 
N total absorvido e Comprimento de MEA LARANJA CAIPIRA

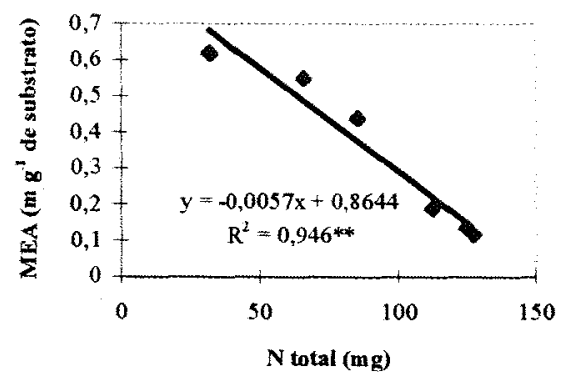

Ca total absorvido e comprimento de MEA LARANJA CAIPIRA

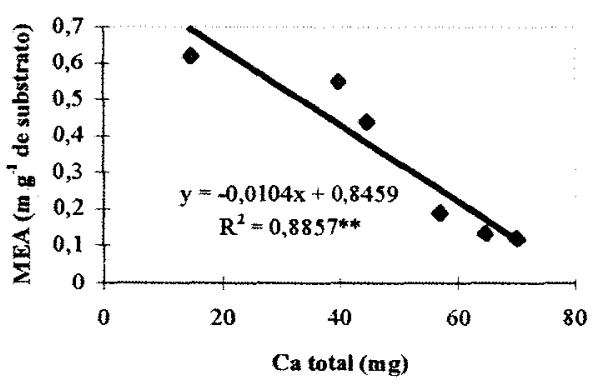

Mg total absorvido e comprimento de MEA LARANJA CAIPIRA

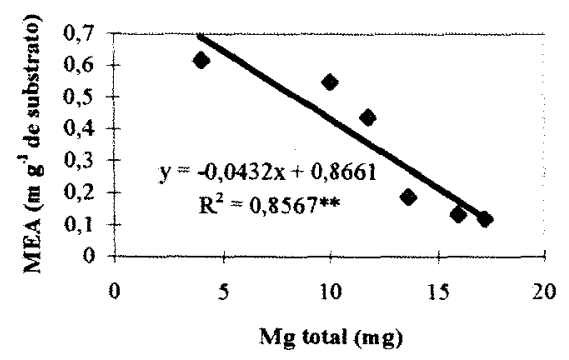

$N$ total absorvido e comprimento de MET TANGERINA CLEÓPATRA

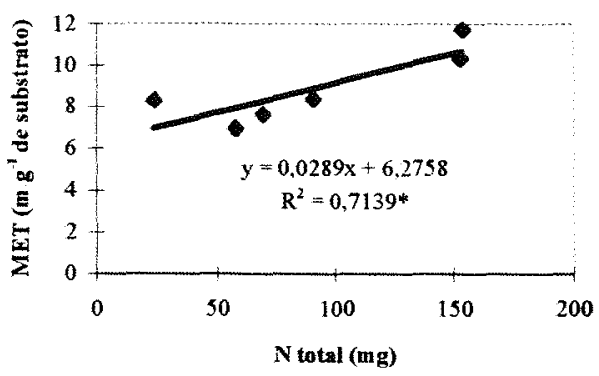

Ca total absorvido e comprimento de MET TANGERINA CLEÓPATRA

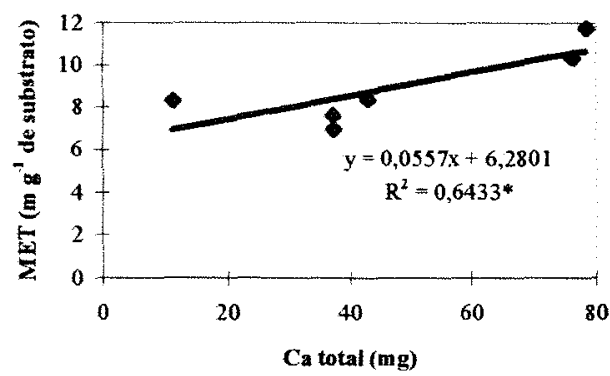

Mg total absorvido e comprimento de MET TANGERINA CLEÓPATRA

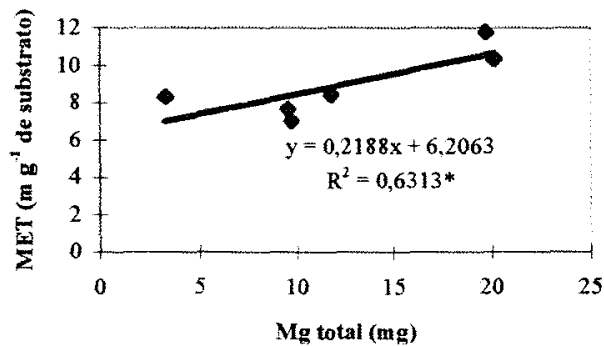

Figura 21. Correlação entre as quantidades totais absorvidas de N, Ca e Mg na parte aérea e comprimento de MEA para laranja caipira e de MET para tangerina cleópatra. 


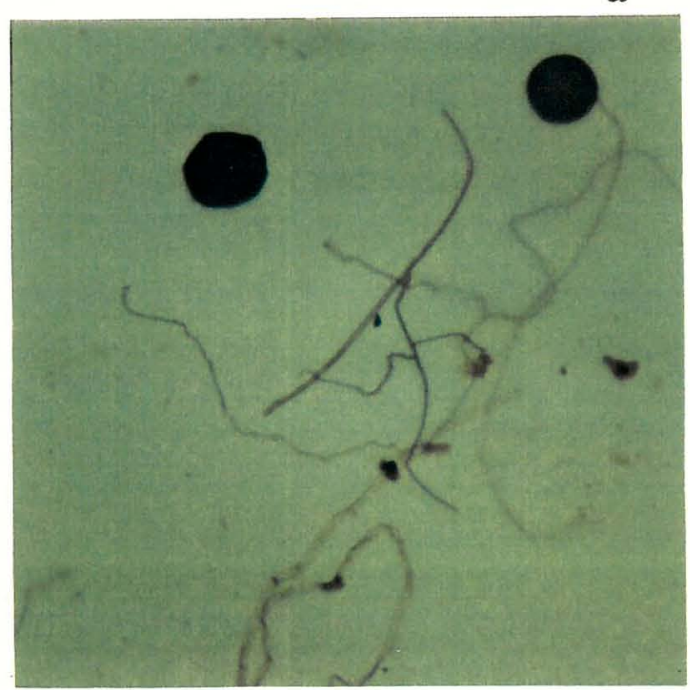

b
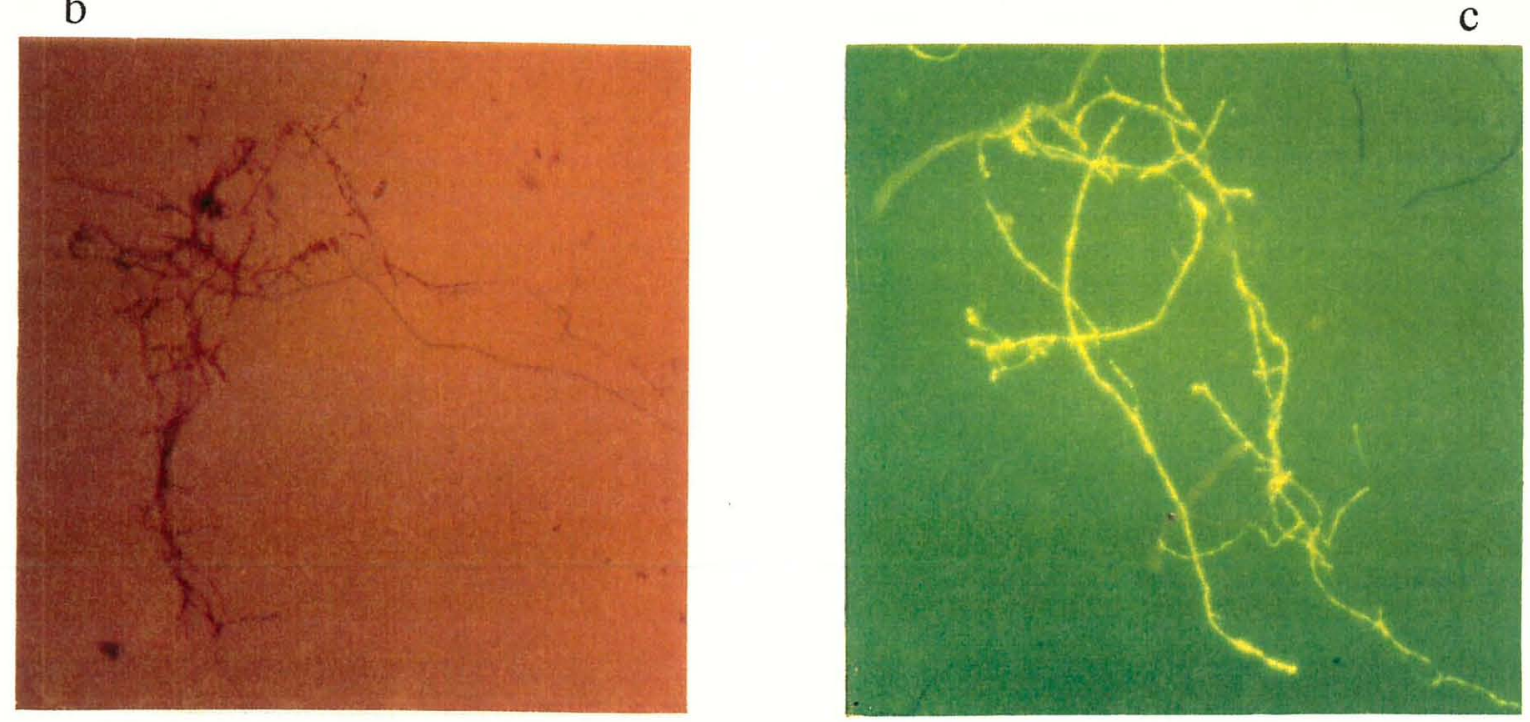

Figura 22. Observações de: MET em luz comum (a); MEA pelo método INT em luz comum (b) e MEA pelo método FDA em luz UV (c), no aumento de $100 x$. 


\section{CONCLUSÕES}

1. O método modificado de extração de micélio extrarradicular de fungos micorrízicos arbusculares do substrato garantiu rapidez e obtenção de micélios mais limpos nas membranas de contagem, sendo que para determinação de atividade, o método de fluorescência induzida com diacetato de fluoresceína (FDA) se destacou pela facilidade de execução e avaliação de micélio ativo, embora não tenha diferido estatisticamente do método da redução de iodonitrotetrazólio (INT) em todas as doses de P para laranja caipira e em doses menores e iguais a $100 \mathrm{mg} \mathrm{P} \mathrm{kg}^{-1}$ de substrato para tangerina cleópatra.

2. Há um comportamento diferenciado de porta-enxertos no comprimento de micélio extrarradicular ativo (MEA) e total (MET) de fungos micorrizicos arbusculares (FMAs), podendo este estar ligado à maior dependência micorrizica na absorção de nutrientes, como observado para tangerina cleópatra, que apresentou maior comprimento de MET e tendência de maior comprimento de MEA em função do acréscimo das doses de $P$.

3. As doses crescentes de $\mathrm{P}$ proporcionaram aumentos nas variáveis altura, diâmetro, matéria seca da parte aérea e quantidade total absorvida de macro e micronutrientes por ambos os porta-enxertos, não sendo suficientemente elevadas para provocar efeito depressivo de crescimento, quando 
micorrizados. A porcentagem de colonização radicular comportou-se de maneira inversa, diminuindo proporcionalmente ao aumento das doses. 


\section{REFERÊNCIAS BIBLIOGRÁFICAS}

ABBOTT, L.K.; ROBSON, A.D. Formation of external hyphae in soil by four species of vesicular-arbuscular mycorrhizal fungi. New Phytologist, v. 99, p. 245-55. 1985.

ABBOTT, L.K.; ROBSON, A.D.; DE BOER, G. The effect of phosphorus on the formation of hyphae in soil by the vesicular-arbuscular mycorrhizal fungus, Glomus fasciculatum. New Phytologist, v. 97, p. 437-46. 1984.

AMBLER, J.R.; YOUNG, J.L. Techniques for determining length infected by vesicular-arbuscular mycorrhizae. Soil Science Society of America Journal, v. 41, p. 551-6. 1977.

AMES, R.N.; INGHAM, E.R.; REID, C.P.P. Ultraviolet-induced autofluorescence of arbuscular mycorrhizal root infections: an alternative to clearing and staining methods for assessing infections. Canadian Journal of Microbiology, v. 28, p. 351-5. 1982.

ANTUNES, V.; CARDOSO, E.J.B.N. Growth and nutrient status of citrus plants as influenced by mycorrhiza and phosphorus application. Plant and Soil, v. 131, p. 11-9. 1991. 
BEEVER, R.E. \& BURNS, D.J.W. Phosphorus uptake, storage and utilization by fungi. In: WOOLHOUSE, H.W. Advances in botanical research, 8. London: Academic Press. 1980. 286p.

BENEFIELD, C.B.; HOWARD, P.J.A.; HOWARD, D.M. The estimation of dehydrogenase in soil. Soil Biology and Biochemistry, v. 9, p. 67-70. 1977.

BETHLENFALVAY, G.J.; AMES, R.N. Comparation of two methods for quantifying extraradical mycelium of vesicular-arbuscular mycorrhizal fungi. Soil Science Society of America Journal, v. 51, p. 834-7. 1987.

BETHLENFALVAY, G.J.; BROWN, M.S.; PACOVSKY, R.S. Relationships between host and endophyte development in mycorrhizal soybeans. New Phytologist, v. 90, p. 537-43. 1982.

BETHLENFALVAY, G.J.; PACOVSKY, R.S.; BROWN, M.S. Measurement of Mycorrizal infection in soybeans. Soil Science Society of America Journal, v. 45 , p. $871-5.1981$.

BIERMANN, B.; LINDERMAN, R.G. Quantifying vesicular-arbuscular mycorrhizae: a proposed method towards standardization. New Phytologist, v. 87, p. $63-7.1981$.

BRADY, N.C. Natureza e Propriedades dos solos. 7.ed. Rio de Janeiro: Freitas Bastos, 1989. cap. 10, p.373-97: Suprimento e assimilabilidade do fósforo e do potássio. 
BUWALDA, J.G.; GOH, K.M. Host-fungus competition for carbon as a cause of growth depressions in vesicular-arbuscular mycorrhizal ryegrass. Soil Biology and Biochemistry, v. 14, p. 103-6. 1982.

CARDOSO, E.J.B.N.; ANTUNES, V.; SILVEIRA, A.P.D.; OLIVEIRA, M.H.A. Eficiência de fungos micorrízicos vesículo-arbusculares em porta-enxertos de citros. Revista Brasileira de Ciência do Solo, v. 10, p. 25-30. 1986.

CARDOSO FILHO, J.A. Quantificação do micélio extramatrical de Glomus etunicatum e da sua atividade, em simbiose com milho. Piracicaba, 1994. 121p. Dissertação (Mestrado) - Escola Superior de Agricultura "Luiz de Queiroz”, Universidade de São Paulo.

COLOZZI-FILHO, A.; SIQUEIRA, J.O. Micorrizas vesículo-arbusculares em mudas de cafeeiro. I. Efeitos de Gigaspora margarita e adubação fosfatada no crescimento e nutrição. Revista Brasileira de Ciência do Solo, v. 10, p. 199-205. 1986.

COLOZZI-FILHO, A.; SIQUEIRA, J.O.; SAGGIN JÚNIOR, O.J.; GUIMARÃES, P.T.G.; OLIVEIRA, E. Efetividade de diferentes fungos micorrízicos arbusculares na formação de mudas, crescimento pós-transplante e produção do cafeeiro. Pesquisa Agropecuária Brasileira, v. 29, n. 9, p. 1397-406. 1994.

COOPER, K.M.; TINKER, P.B. Translocation and transfer of nutrients in vesicular-arbuscular mycorrhizas - IV. Effect of environmental variables on movement of phosphorus. New Phytologist, v. 88, p. 327-39. 1981. 
CRUSH, J.R. Endomycorrhizas and legume growth in some soils of the Mackenzie Basin, Canterbury, New Zealand. New Zealand Journal of Agricultural Research, v. 19, p. 473-6. 1976.

DARKEN, M.A. Natural and induced fluorescence in microscopic organisms. Applied Microbiology, v. 9, p. 354-60. 1961.

EISSENSTAT, D.M.; GRAHAM, J.H. Regulation of mycorrhizal colonization among citrus genotypes: cost versus benefit in relation to phosphorus supply. In: NORTH AMERICAN CONFERENCE ON MYCORRHIZAE, 8., Jackson, 1990. Abstracts. Jackson, 1990. p.93.

FERNANDES, A.B.; SIQUEIRA, J.O.; MENEZES, M.A.L.; GUEDES, G.A.A. Efeito diferenciado do fósforo sobre o estabelecimento e efetividade da simbiose endomicorrizica em milho e soja. Revista Brasileira de Ciência do Solo, v. 11, p. 101-8. 1987.

FONSECA, E.B.A.; OLIVEIRA, E.; SOUZA, M.; CARVALHO, J.G. Efeitos do fósforo e fungo MVA na nutrição de dois porta-enxertos de citros. Pesquisa Agropecuária Brasileira, v. 29, n. 12, p. 1889-96. 1994.

FREY, B.; VILARIÑO, A.; SCHÜEPP, H.; ARINES, J. Chitin and ergosterol content of extraradical and intraradical mycelium of the vesicular-arbuscular mycorrhizal fungus Glomus intraradices. Soil Biology and Biochemistry, v. 26, n. 6, p. 711-7. 1994.

GIOVANETTI, M.; MOSSE, B. An evaluation of techniques for measuring vesicular arbuscular mycorrhizal infection in roots. New Phytologist, v. 84, p. $489-500.1980$. 
GRAHAM, J.H.; LEONARD, R.T.; MENGE, J.A. Membrane-mediated decrease in root exsudation responsible for phosphorus inhibition of vesiculararbuscular mycorrhiza formation. Plant Physiology, v. 68, p. 548-52. 1981.

GRAHAM, J.H.; LINDERMAN, R.G.; MENGE, J.A. Development of external hyphae by different isolates of mycorrhizal Glomus spp. in relation to root colonization and growth of troyer citrange. New Phytologist, v. 91, p. 183-9. 1982.

HALL, I.R.; KELSON, A. An improved technique for the production of endomycorrhizal infested soil pellets. New Zealand Journal of Agricultural Research, v. 24, p. 221-2. 1981.

HALL, I.R.; SCOTT, R.S.; JOHNSTONE, P.D. Effect of vesicular-arbuscular mycorrhizas on response of "Grasslands Huia" and "Tamar" white clovers to phosphorus. New Zealand Journal of Agricultural Research, v. 20, p. 34955. 1977.

HAMEL, C.; FYLES, H.; SMITH, D.L. Measurement of development of endomycorrhizal mycelium using three different vital stains. New Phytologist, v. 115, p. 297-302. 1990.

HARDIE, K. The effect of removal of extraradical hyphae on water uptake by vesicular-arbuscular mycorrhizal plants. New Phytologist, v. 101, p. 677-84. 1985.

HARLEY, J.L. \& SMITH, S.E. Mycorrhizal symbiosis. London: Academic Press, 1983. cap.4, p.77-103: Mineral Nutrition. 
HEPPER, C.M. A colorimetric method for estimating vesicular-arbuscular mycorrhizal infection in roots. Soil Biology and Biochemistry, v. 9, p. 15-8. 1977.

INGHAM, E.R.; KLEIN, D.A. Soil fungi: relationships between hyphal activity and staining with fluorescein diacetate. Soil Biology and Biochemistry, v. 16, n. 3, p. 273-8. 1984.

JAKOBSEN, I.; JONER, E.J.; LARSEN, J. Hyphal phosphorus transport, a keystone to mycorrhizal enhancement of plant growth. In: GIANINAZZI, S; SCHÜEPP, H., ed. Impact of arbuscular mycorrhizas on sustainable agriculture and natural ecosystems. Basel, Boston, Berlin: Birkhäuser, 1994. cap.11, p. 133-46.

JAKOBSEN, I.; ABBOTT, L.K.; ROBSON, A.D. External hyphae of vesiculararbuscular mycorrhizal fungi associated with Trifolium subterraneum L. 1. Spread of hyphae and phosphorus inflow into roots. New Phytologist, v. 120, p. 371-80. 1992.

JASPER, D.A.; ABBOTT, L.K.; ROBSON, A.D. Soil disturbance reduces the infectivity of external hyphae of vesicular-arbuscular mycorrhizal fungi. New Phytologist, v. 112, p. 93-9. 1989.

JASPER, D.A.; ROBSON, A.D.; ABBOTT, L.K. Phosphorus and the formation of vesicular-arbuscular mycorrhizas. Soil Biology and Biochemistry, v. 11, p. 501-5. 1979. 
JAYACHANDRAN, K.; SCHWAB, A.P.; HETRICK, B.A.D. Mineralization of organic phosphorus by vesicular-arbuscular mycorrhizal fungi. Soil Biology and Biochemistry, v. 24, n. 9, p. 897-903. 1992.

JOHNSON, B.N.; McGILL, W.B. Comparison of ergosterol and chitin as quantitatite estimates of mycorrhizal infection and Pinus contorta seedling response to inoculation. Canadian Journal of Forest Research, v. 20, p. 1125-31. 1990.

KIEHL, E.J. Fertilizantes organominerais. Piracicaba: Edição do autor, 1993. $189 \mathrm{p}$.

KORMANIK, P.P.; BRYAN, W.C.; SCHULTZ, R.C. Procedures and equipament for staining large numbers of plant root samples for endomycorrhizal assay. Canadian Journal of Microbiology, v. 26, p. 536-8. 1980.

KORMANIK, P.P.; McGRAW, A.C. Quantification of vesicular-arbuscular mycorrhizae in plant roots. In: SCHENCK, N.C. (ed.) Methods and Principles of Mycorrhizal Research. St Paul, The American Phytopathological Society. 1982. 244p.

KOUGH, J.; MALAJCZUK, N.; LINDERMAN, R.G. Use of the indirect immunofluorescent technique to study the vesicular-arbuscular fungus Glomus epigaeum and other Glomus species. New Phytologist, v. 94, p. 5762. 1983.

KUCEY, R.M.N.; PAUL, E.A. Biomass of mycorrhizal fungi associated with bean roots. Soil Biology and Biochemistry, v. 14, p. 413-4. 1982. 
LAMBAIS, M.R.; CARDOSO, E.J.B.N. Avaliação da germinação de esporos de fungos micorrizicos vesículo-arbusculares e da colonização micorrízica de Stylosanthes guianensis em solo ácido e distrófico. Revista Brasileira de Ciência do Solo, v. 12, p. 249-55. 1988.

LAMBAIS, M.R.; CARDOSO, E.J.B.N. Response of Stylosanthes guianensis to endomycorrhizal fungi inoculation as affected by lime and phosphorus applications. I. Plant growth and development. Plant and Soil, v. 129, p. 283-9. 1990.

LAMBAIS, M.R.; MEHDY, M.C. Suppression of endochitinase, $\beta-1,3-$ endoglucanase, and chalcone isomerase expression in bean vesiculararbuscular mycorrhizal roots under different soil phosphate conditions. Molecular Plant-Microbe Interactions, v. 6, n. 1, p. 75-83. 1993.

LAMBAIS, M.R.; MEHDY, M.C. Different expression of defense-related genes in arbuscular mycorrhiza. Canadian Journal of Botany, v. 73, p. 533-40. 1995.

LAMBAIS, M.R.; MEHDY, M.C. Soybean roots infected by Glomus intraradices Shenk \& Smith strains differing in infectivity exhibit differential chitinase and $\beta$-1,3-glucanase expression. New Phytologist, 1996. (No prelo).

LAMBERT, D.H.; BAKER, D.E.; COLE JR, H. The role of mycorrhizae in the interactions of phosphorus with zinc, copper, and other elements. Soil Science Society of America Journal, v. 43, p. 976-80. 1979.

LEVY, Y.; KRIKUN, J. Effect of vesicular-arbuscular mycorrhiza on Citmus jambhiri water relations. New Phytologist, v. 85, p. 25-31. 1980. 
LOBO, M.G.; SILVA, R.M. Produção de fertilizantes fosfatados. In: SIMPÓSIO SOBRE FERTILIZANTES NA AGRICULTURA BRASILEIRA, Brasília, 1984. Trabalhos apresentados. Brasília: EMBRAPA-DEP, 1984. p.73-115.

MEDZON, E.L.; BRADY, M.L. Direct measurement of acetylsterase in living protist cells. Journal of Bacteriology, v. 97, n. 1, p. 402-15. 1969.

MELLONI, R.; NOGUEIRA, M.A.; FREIRE, V.F.; CARDOSO, E.J.B.N. Avaliação do estado nutricional de limoeiro cravo (Citrus limonia) submetido à doses crescentes de fósforo e espécies de fungos micorrizicos arbusculares. In: REUNIÃO BRASILEIRA DE FERTILIDADE DO SOLO E NUTRIÇÃO DE PLANTAS, 22. Manaus, 1996. Trabalhos apresentados. Manaus, 1996a.

MELLONI, R.; NOGUEIRA, M.A.; FREIRE, V.F.; CARDOSO, E.J.B.N. Efeito de doses de fósforo e fungos micorrízicos arbusculares no crescimento de mudas de limão cravo (Citrus limonia L. Osbeck). In: CONGRESSO LATINO AMERICANO DE CIÊNCIA DO SOLO, 13., Águas de Lindóia, 1996. Trabalhos apresentados. CD-ROM, 1996 b.

MENGE, J.A.; LABANAUSKAS, C.K.; JOHNSON, E.L.V.; PLATT, R.G. Partial substitution of mycorrhizal fungi for phosphorus fertilization in the greenhouse culture of Citrus. Soil Science Society of America Journal, v. 42, p. 926-30. 1978.

MILLER, R.M.; JARSTFER, A.G.; PILLAI, J.K. Biomass allocation in an Agropyron smithii-Glomus symbiosis. American Journal of Botany, v. 74, n. 1, p. $114-22.1987$. 
MIRANDA, J.C.C.; HARRIS, P.J. Effects of soil phosphorus on spore germination and hyphal growth of arbuscular mycorrhizal fungi. New Phytologist, v. 128, p. 103-8. 1994a.

MIRANDA, J.C.C.; HARRIS, P.J. The effect of soil phosphorus on the external mycelium growth of arbuscular mycorrhizal fungi during the early stages of mycorrhiza formation. Plant and Soil, v. 166, p. 271-80. 1994 b.

MIRANDA, J.C.C.; HARRIS, P.J.; WILD, A. Effects of soil and plant phosphorus concentrations on vesicular-arbuscular mycorrhiza in sorghum plants. New Phytologist, v. 112, p. 405-10. 1989.

MOSSE, B.; PHILLIPS, J.M. The influence of phosphate and other nutrients on the development of vesicular-arbuscular mycorrhiza in culture. Journal of General Microbiology, v. 69, p. 157-66. 1971.

NEWMAN, E.I. A method for estimating the total lenght of root in a sample. Journal of Applied Ecology, v. 3, p. 139-45. 1966.

OJALA, J.C.; JARRELL, W.M.; MENGE, J.A.; JOHNSON, E.L.V. Comparison of soil phosphorus extractants as predictors of mycorrhizal dependency. Soil Science Society of America Journal, v. 47, p. 958-62. 1983.

OLIVEIRA, A.A.R.; JESUS, I.S. Efeito da infecção por fungos micorrizicos vesicular-arbusculares sobre o desenvolvimento de porta-enxertos de citros. Congresso Brasileiro de Fruticultura, v. 9, p. 319-25. 1987. 
PACOVSKY, R.S.; BETHLENFALVAY, G.J. Measurement of the extraradical mycelium of a vesicular-arbuscular mycorrhizal fungus in soil by chitin determination. Plant and Soil, v. 68, p. 143-7. 1982.

PENG, S.; EISSENSTAT, D.M.; GRAHAM, J.H.; WILLIAMS, K.; HODGE, N.C. Growth depression in mycorrhizal citrus at high-phosphorus supply. Plant Physiology, v. 101, p. 1063-71. 1993.

PHILLIPS, J.M.; HAYMAN, D.S. Improved procedures for clearing roots and staining parasitic and vesicular-arbuscular mycorrhizal fungi for rapid assessment of infection. Transactions of the British of Mycological Society, v. 55, n. 1, p. $158-60.1970$.

REENA, J.; BAGYARAJ, D.J. Growth stimulation of Tamarindus indica by selected VA mycorrhizal fungi. World Journal of Microbiology and Biotechnology, v. 6, p. 59-63. 1990.

REICOSKY, D.C.; MILLINGTON, R.J.; PETERS, D.B. A comparison of three methods for estimating root length. Agronomy Journal, v. 62, p. 451-3. 1970.

RHODES, L.H.; GERDEMANN, J.W. 'Translocation of calcium and phosphate by external hyphae of vesicular-arbuscular mycorrhizae. Soil Science, v. 126, $\mathrm{n}$. 2, p. 125-6. 1978.

ROSER, D.J.; KEANE, P.J.; PITTAWAY, P.A. Fluorescent staining of fungi from soil and plant tissues with ethidium bromide. Transactions of the British Mycological Society, v. 79, n. 2, p. 321-9. 1982. 
ROWSE, H.R.; PHILLIPS, D.A. An instrument for estimating the total length of root in a sample. Journal of Applied Ecology, v. 11, p. 309-14. 1974.

SARRUGE, J.R.; HAAG, H.P. Análises químicas em plantas. Piracicaba: ESALQ, 1974. 56p.

SCHUBERT, A.; MARZACHÍ, C.; MAZZITELLI, M.; CRAVERO, M.C.; BONFANTE-FASOLO, P. Development of total and viable extraradical mycelium in the vesicular-arbuscular mycorrhizal fungus Glomus clarum Nicol. \& Schenck. New Phytologist, v. 107, p. 183-90. 1987.

SCHWAB, S.M.; MENGE, J.A.; LEONARD, R.T. Comparison of stages of vesicular-arbuscular mycorrhiza formation in sudangrass gown at two levels of phosphorus nutrition. American Journal of Botany, v. 70, n. 8, p. 122532. 1983.

SHARMA, P.D.; FISHER, P.J.; WEBSTER, J. Critique of the chitin assay techique for estimation of fungal biomass. Transactions of the British Mycological Society, v. 69, n. 3, p. 479-83. 1977.

SILVA, L.R.C.; PEREIRA, J.; AZEVEDO, I.C. Efeito de fontes de fósforo sobre o crescimento micelial de Gigaspora gigantea in vitro. Revista Brasileira de Ciência do Solo, v. 15, p. 169-72. 1991.

SILVEIRA, A.P.D.; CARDOSO, E.J.B.N. Influência da micorriza vesículoarbuscular nos parâmetros cinéticos de absorção de $\mathrm{P}$, no crescimento $\mathrm{e}$ nutrição do feijoeiro em dois estádios do ciclo da planta. In: REUNIÃO BRASILEIRA SOBRE MICORRIZAS, 4., Mendes, 1991. Trabalhos apresentados. Mendes: EMBRAPA, UFRRJ, 1991. p.144. 
SILVEIRA, A.P.D. Micorrizas. In: CARDOSO, E.J.B.N.; TSAI, S.M.; NEVES, M.C.P., ed. Microbiologia do solo. Campinas: Sociedade Brasileira de Ciência do Solo, 1992. cap. 19, p. 257-82.

SIQUEIRA, J.O.; HUBBELL, D.H.; VALLE, R.R. Effects of phosphorus on formation of the vesicular-arbuscular mycorhizal symbiosis. Pesquisa Agropecuária Brasileira, v. 19, n. 12, p. 1465-74. 1984.

SIQUEIRA, J.O; COLOZZI-FILHO, A. Micorrizas vesículo-arbusculares em mudas de cafeeiro. II. Efeito do fósforo no estabelecimento e funcionamento da simbiose. Revista Brasileira de Ciência do Solo, v. 10, p. 207-11. 1986.

SIQUEIRA, J.O.; COLOZZI-FILHO, A.; FARIA, F.H.S.; OLIVEIRA, E. Efetividade simbiótica de fungos micorrizicos vesículo-arbusculares para o algodoeiro. Revista Brasileira de Ciência do Solo, v. 10, p. 213-8. 1986.

SNELLGROVE, R.C.; SPLITTSTOESSER, W.E.; STRIBLEY, D.P.; TINKER, P.B. The distribution of carbon and the demand of the fungal symbiont in leek plants with vesicular-arbuscular mycorrhizas. New Phytologist, v. 92, p. 75-87. 1982.

SÖDERSTRÖM, B.E. Vital staining of fungi in pure cultures and in soil with fluorescein diacetate. Soil Biology and Biochemistry, v. 9, p. 59-63. 1977.

SOUZA, E.F.O.; SOUZA, M.; OLIVEIRA, E. Efeito de fungos MVA e fósforo sobre o crescimento do limoeiro cravo (Citrus limonia OSBEC"K), pós repicagem. Ciência e Prática, v. 15, n. 4, p. 398-404. 1991. 
STRIBLEY, D.P.; TINKER, P.B.; RAYNER, J.H. Relation of internal phosphorus concentration and plant weight in plants infected by vesicular-arbuscular mycorrhizas. New Phytologist, v. 86, p. 261-6. 1980.

SUTTON, J.C.; SHEPPARD, B.R. Aggregation of sand-dune soil by endomycorrhizal fungi. Canadian Journal of Botany, v. 54, p. 326-33. 1976.

SYLVIA, D.M. Activity of external hyphae of vesicular-arbuscular mycorrhizal fungi. Soil Biology and Biochemistry, v. 20, n. 1, p. 39-43. 1988.

SYLVIA, D.M. Quantification of external hyphae of vesicular-arbuscular mycorrhizal fungi. Methods in Microbiology, v. 24, p. 54-65. 1992.

SYLVIA, D.M. Spatial and temporal distribution of vesicular-arbuscular mycorrhizal fungi associated with Uniola paniculata in Florida foredunes. Mycologia, v. 78, n. 5, p. 728-34. 1986.

THOMSON, B.D.; ROBSON, A.D.; ABBOTT, L.K. Effects of phosphorus on the formation of mycorrhizas by Gigaspora calospora and Glomus fasciculatum in relation to root carbohydrates. New Phytologist, v. 103, p. 751-65. 1986.

TOBAR, R.; AZCÓN, R.; BAREA, J.M. Improved nitrogen uptake and transport from $15 \mathrm{~N}$-labelled nitrate by external hyphae of arbuscular mycorrhiza under water-stressed conditions. New Phytologist, v. 126, p. 119-22. 1994.

TOTH, R.; TOTH, D. Quantifying vesicular-arbuscular mycorrhyzae using a morphometric technique. Mycologia, v. 74, n. 2, p. 182-7. 1982. 
VEEN, J.A. van ; PAUL, E.A. Conversion of biovolume measurements of soil organisms, grown under various moisture tensions, to biomass and their nutrient content. Applied and Environmental Microbiology, v. 37, n. 4, p. 686-92. 1979.

VILARIÑO, A.; ARINES, J.; SCHÜEPP, H. Extraction of vesicular-arbuscular mycorrhizal mycelium from sand samples. Soil Biology and Biochemistry, v. 25, n. 1, p. 99-100. 1993.

XIAO-LIN, L.; GEORGE, E.; MARSCHNER, H. Extension of the phosphorus depletion zone in VA-mycorrhizal white clover in a calcareous soil. Plant and Soil, v. 136, p. 41-8. 1991.

WILSON, J.M.; TRINICK, M.J.; PARKER, C.A. The identification of vesiculararbuscular mycorrhizal fungi using immunofluorescence. Soil Biology and Biochemistry, v. 15, n. 4, p. 439-45. 1983.

WU, C.H.; WARREN, H.L. Induced autofluorescence in fungi and its correlation with viability: potencial application of fluorescence microscopy. Phytopathology, v. 74, n. 11, p. 1353-8. 1984a.

WU, C.H.; WARREN, H.L. Natural autofluorescence in fungi and its correlation wih viability. Mycologia, v. 76, n. 6, p. 1049-58, 1984 b.

ZAMBOLIM, L.; SIQUEIRA, J.O. Importância e potencial das associações micorrízicas para a agricultura. Série Documentos, v. 26. 1985. 